Historic, Archive Document

Do not assume content reflects current scientific knowledge, policies, or practices. 



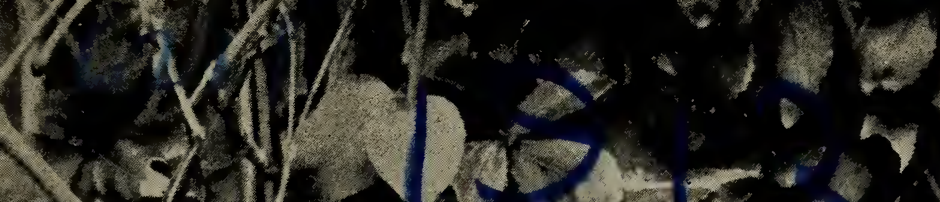

(100)

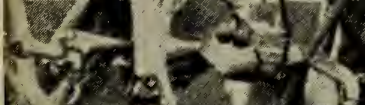

$\rightarrow$

1)

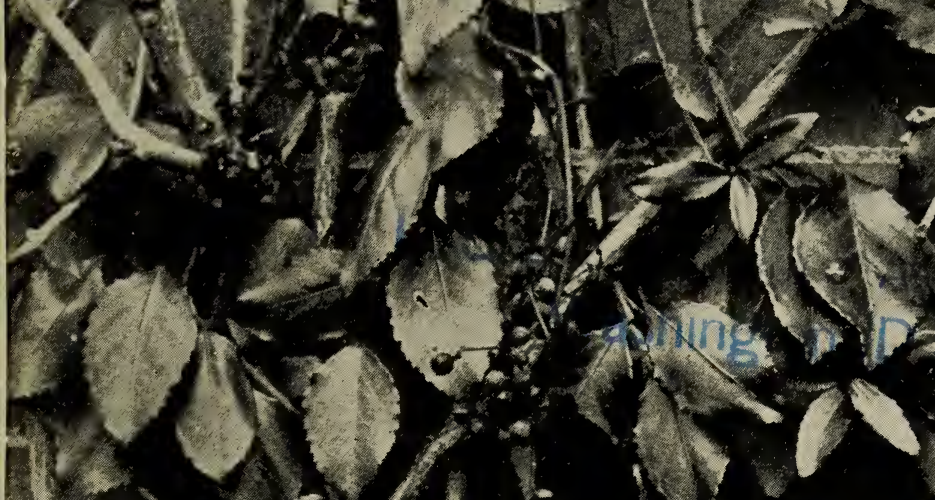

nols. in

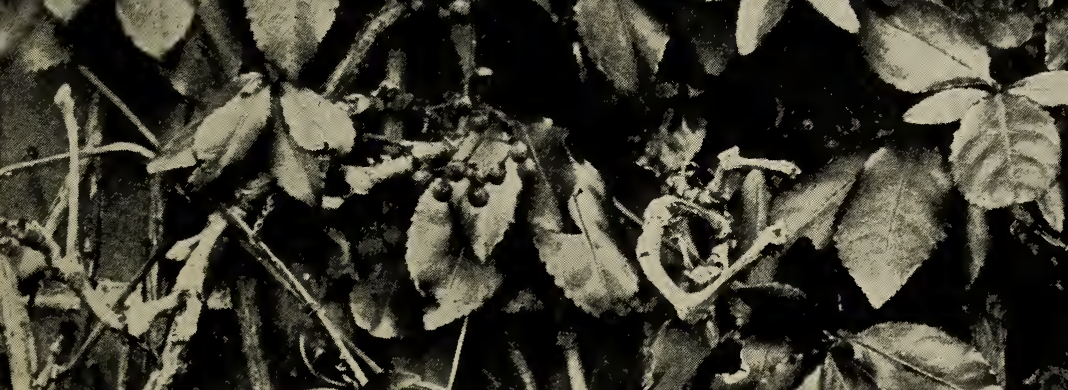

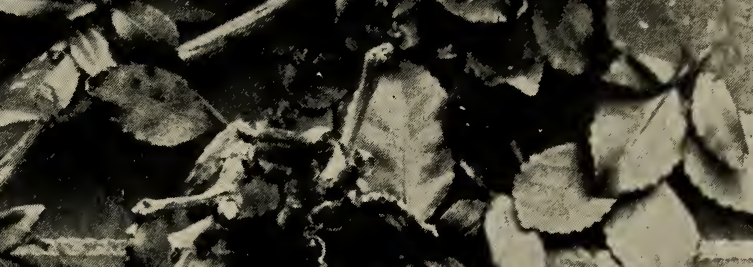





\section{TO THE CUSTOMER.}

Order Early. It will greatly facilitate the handling of your business if you will send in your order early. Send on your order and pay later if more convenient. Remember, the planting season is short. Be on time. Do not lose a year.

Prices include packing for shipment but transrortation is to be paid by the pur. chaser.

Forwarding.. I guarantee safe delivery of all express shipments, and will replace losses free which occur during transit if recorted cromptly.

The express rate on trees and plants is "General Special," which is as follows per 100 pounds: Boulder to Denver, 40 cents; to Fort Collins and Greeley, 50 cents; to Colorado Springs and Pueb?o, $\$ 1.00$; to Rocky Ford and Salida, $\$ 1.50$; to Durango, Montrose and Grand Junction, $\$ 2.50$. Thirty five cents will carry 80 pounds to Denver, 70 rounds to Fort Collins and Greeley, 35 pounds to Co.orado Springs and Pueblo, or 14 rounds to Grand Junction.

Parcel Post rate on p.ants and seeds is 8 cents per pound for all distances; limit 11 pounds.

Heavy shipments will be sent by freight unless customer directs otherwise.

Packing. If there is one vital roint which means more to the purchaser than any other it is good packing. The difference between good packing and bad packing is exactly the difference between success and failure.

My system of packing is so nearly perfect that I ship many thousands of plants each season to England and var:ous parts of Europe without any loss whatever. Last November I sent a shipment of Roses. Lilacs, Iris, etc., to a friend in China, and have just learned that they reached their destination in splendid condition, after being a little more than a month on the way.

My customers anywhere in Colorado will receive their plants just as fresh and full of life as if they lived next aoor. No matter where you live, I want to make it to your advantage, price, quality, convenience and all things considered, to buy from Rockmont Nursery.

Reliability of Stock. Few nurseries in this country exercise greater care than I do to send out stock that is strictly true to name. I obtain my original stocks from reliable sources, keep them marked with indestructible labels of my own invention, verify everything when in growth or bloom and personally oversee digging and packing. I do all this because I cannot feel satisfied with less. When mistakes occur, I am only too glad to correct them to the satisfaction of the customer.

Inspection. My nurseries have been inspected by a duly authorized inspector from the office of the State Entomologist, and were found free from insect pests and diseases. Certificate with every shipment.

Correspondence. I am always glad to hear from anyone regarding any phase of ornamental or economic planting, and the result of my experience is always available for anyone who will apply. Letters of inquiry should be written on a separate sheet from orders, and questions should be stated clearly and briefly, and if possible before April and May when the business of delivering orders requires my entire time.

Again I say, no matter where you live, I want to make it to your advantage, price, quality, convenience and all things considered, to buy from Rockmont Nursery.

Yours very truly,

February, 1913.

D. M. ANDREWS. 


\section{Planting and Care of Trees for Colorado}

My "Little Red Book" of twenty pages on the above subject is free to my customers and their tree planting friends. If you have failed to receive a copy it will be mailed upon request. Send the addresses of two or three friends who plant trees and I will send them copies also.

\section{CATALOGUE COVER ILLUSTRATION.}

This year I have the Evergreen Bittersweet or Japanese Ivy (Euonymus radicans). It is growing on the north wall of my office with the Engelman Ivy (Ampelopsis), and was photographed last December after the leaves of the latter had fallen. Now, after the coldest weather for many winters, the foliage is as fresh and green as in midsummer.

Wilhelm Miller, writing for the Garden Magazine says: "If I had a million dollars to spare, I should like to plant an Evergreen Bittersweet on every stone, brick and concrete wall in America. The effect would be electrical, for it would add 100 per cent to the beauty of America."

In order to have this climb to a considerable height it should be planted with the Engelmann Ivy which affords the necessary support, and no tacking or other fastening is required. All that is needed is to plant the two vines, one of each, near the wall and not more than a foot apart. A north or east exposure is recommended, as west wind and winter sunshine are very trying on any kind of evergreen foliage. For prices, see page 12 .

\section{LATIN SYNONYMS FOR ENGLISH PLANT NAMES.}

Alder-Alnus

Ash-Fraxinus

Baby's Breath-Gypsophila

Barberry-Berberis

Basswood-Tilia

Bellflower-Platycodon

Birch-Betula

Bird Cherry-Prunus

Bittersweet-Celastrus

Bittersweet Evergreen-Euonymus

Black Walnut-Juglans

Black Locust-Robinia

Bleeding Heart-Dicentra

Blue Spruce-Picea

Boston Ivy-Ampelopsis

Burning Bush-Euonymus

Cedar-Juniperus

Choke Cherry-Prunus

Columbine-Aquilegia

Cottonwood-Populus

Crab, flowering-Malus

Cranberry tree-Viburnum

Currant, flowering-Ribes

Dogwood-Cornus

Elder-Sambucus

Elm-Ulmus

Englemann Ivy-Ampelopsis

English Ivy-Hedera

Flag, Fleur de Lis-Iris

Gooseberry, wild-Ribes

Grape, wild-Vitis

Hackberry-Celtis
Hawthorn-Crataegus

Honey Locust-Gleditsia

Honeysuckle-Lonicera

Horse Chestnut-Aesculus

Indian Currant-Symphoricarpos

Japan Quince-Cydonia

Kentucky Coffee Tree-Gymnocladus

Larkspur-Delphinium

Lilac-Syringa

Linden-Tilia

locust, Black-Robinia

Locust, Honey-Gleditsia

Mallow Marvels-Hibuscus

Maple-Acer

Mountain Ash-Sorbus

Ninebark-Opulaster

Oak-Quercus

Olive, Russian-Elaeagnus

Privet-Ligustrum

Red Hot Poker-Tritoma

Rose Mallow-Hibiscus

Silver Cedar-Juniperus

Snowberry-Symphoricarpos

Snowball-Viburnum

Spruce-Picea

Sumach-Rhus

Syringa-Philadelphus

Thimbleberry-Rubus

Thorn, Thorn Apple-Crataegus

Torch Lily-Tritoma

Walnut-Juglans

Willow-Salix 


\section{3}

\section{General Catalogue of}

\section{ROCKMONT NURSERY}

D. M. ANDREWS, Owner

BOULDER，COLORADO

ESTABLISHED 1893

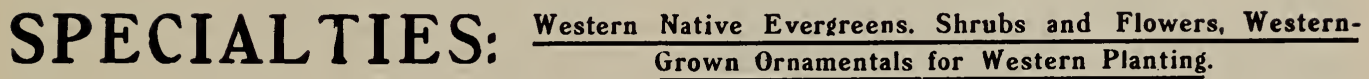

\section{DECIDUOUS TREES}

For a number of years, both in my catalogue and otherwise, I have been advocating the planting of better trees. The day has passed when necessity compels the exclusive use of Cottonwoods, Carolina Poplar, Soft Maple and Box Elder. I do not say that none of these should be planted, but I do say that every one who plants a tree owes it to himself and to his fellows to select the best tree for the place, because a tree, no matter where planted, becomes an object of interest to the entire community. Buy from a responsible nursery, plant well and follow up with good care and you will have added to the pleasure of yourself and others.

I have been told that I would not find this policy profitable,--that people would not heed the advice, to plant better trees. I went into it without expecting great results immediately, but a favorable response all along the line has come sooner than I expected, and there is a steadily increasing demand in all the tree planting centers of the state for the excellent varieties offered on the following pages.

Every customer may have for the asking, a copy of my "Little Red Book" on Planting and Care of Trees, the purpose of which is to establish a higher standard relating to the principles which pertain to better trees, better planting and better care. This should mean greater success and more satisfaction to those who plant trees.

My list of trees on the following pages has ben carefully selected from kinds which are known to be growing and thriving in Colorado. The descriptions are intended to convey a fair, and truthful impression, disclosing faults where they exist. Not only do I advocate and offer the very best kinds for the climate, but I deliver only select, straight specimens with good root and top development. They are carefully grown for discriminating buyers who appreciate quality as well as economy, and who place a proper valuation upon absolute reliability.

The asterisk (*) indicates native Colorado species 


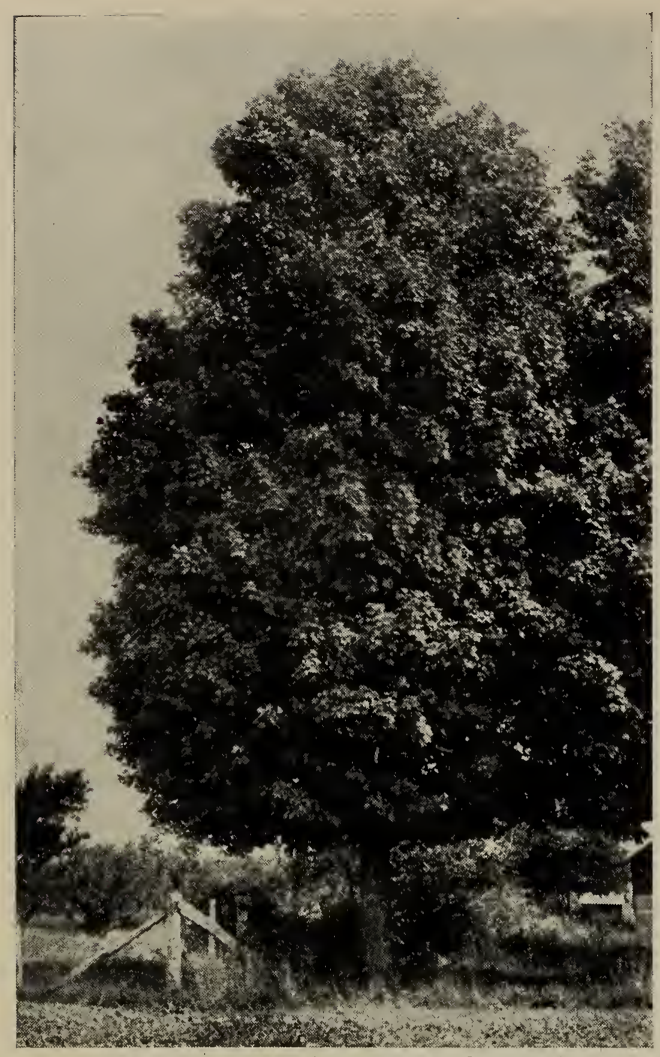

Hard Maple, (Acer Saccharum)

\section{ACER-MAPLES.}

In this group will be found a number of our hardiest and most valuable shade and ornamental trees, ranging from shrubs to trees of largest size, having varied and unusually attractive foliage. Their graceful and artistic proportions and autumn colors add greatly to their attractiveness.

Acer ginnala, Siberian Maple. A large shrub of graceful appearance with handsome three-lobed foliage turning bright red in autumn. May be used in this region instead of the less hardy Japanese Maples. 6-8 feet, 75 cents; $6-8$ feet heavy clumps, $\$ 1.00$.

*Acer glabrum, Rocky Mountain Maple. The large shrubby, maple of the mountains; dense bushy habit, well rounded symmetrical outlines, hardy and adapted for dry positions. 4-6 feet, 75 cents.

Acer platanoides, Norway Maple. A large tree of quite rapid growth, compact rounded head, dark luxuriant foliage turning bright yellow in autumn. A tree of splendid appearance, valuable for street planting, shade or ornament, hardy, vigorous and well suited to our climate. $6-8$ feet, 75 cents; $8-10$ feet, $\$ 1.25$.

Acer platanoides Schwedleri, Schwedler's
Norway Maple. A variety with blood-red foliage in spring, gradually changing to dark green with purplish, autumn shades. Grafted trees, 6-8 feet, $\$ 1.25$.

Acer pseudo-platanus, Sycamore Maple. A large, vigorous, hardy tree of rather urright growth, leaves large, five lobed, dark green, yellow in autumn. This and the Norway, belong to the Hard Maples, but are more rapid growers than the American Hard Maple; 6-8 feet, 75 cents.

Acer rubrum, Scarlet Maple. A large slow-growing tree of excellent habit, attractive at all seasons, but especially in autumn, the foliage assuming ..le most gcrgeous shades of red and scarlet; 6.8 feet, $\$ 1.00$.

Acer saccharinum, (A. dasycarpum) So tit or Silver Maple. A large tree of very rapid growth, slender spreading branches, rather easily broken by wind or snow. This is not the Silver-leaved Poplar which is often miscalled Silver-leaved Maple. 10-12 feet, $\$ 1.25$.

Acer saccharinum Wieri, Wier's Cut Leaf Maple. A rapid growing variety with ele-/D gant finely cut foliage, and weeping branches; 6-8 feet, 75 cents.

Acer saccharum, Hard or Sugar Maple. A large growing, long lived tree of upright dense habit, thriving in almost any soil, making the best development in moist loam Valuable in this region as a street tree and for other purposes where rapid growth is not essential. Its hardiness, freedom from insects and disease, refined and stately appearance commend it to more general use. 6-8 feet, 75 cents; 8-10 feet, $\$ 1.00$.

Acer saccharum nigrum, Black Sugar Maple. A large tree with dark bark and more spreading habit than the Sugar Maple. Native of Illinois, where it is commonly used for shade and street planting; 6-8 feet, $\$ 1.00$.

\section{AESCULUS-HORSE CHESTNUT.}

Handsome flowering trees, very hardy and extremely adaptable, prefering moist loamy soils.

Aesculus Hippocastaneum, European Horse Chestnut. A large tree of very symmetrical, somewhat formal habit and compact growth, affording a dense shade. Flowers very showy, white, followed by the characteristic fruits. Everywhere highly esteemed and is one of the successful trees for Colorado. Should be wrapped with burlap or sacking the first winter. 5-6 feet, $\$ 1.00$.

\section{ALNUS-ALDER.}

*Alnus tenuifolius, Rocky Mountain Ald. er. A small native tree especially valuable for wet places. 5-6 feet, 50 cents.

\section{BETULA-BIRCHES.}

The Birches are trees of rather slender growth and graceful habit. Their pictur-

a dozen for the price of ten. 
esque trunks clothed with parery bark are especially attractive in winter, and this effect may be intensified by a judicious combination with evergreens. They are sometimes injured during extremely dry winters and on this account they are apt to succeed best in soils somewhat retentive of moisture. The following are the hardiest for this climate:

Betula alba pendula laciniata, Cut-leaved Weeping Birch. A variety of the European White Birch with very slender cendulou; branches and beautifully cut foliage. 'The finest of weeping trees. 5-6 feet, $\$ 1.00$.

* Betula fontinalis, Rocky Mountain Birch. The large shrubby species common along streams, with purplish brown bark and twigs. The hardiest Birch for this region, but never attaining large size. 4-i feet, 75 cents.

Betula papyrifera, Paper or Canoe Birch. The Canoe Birch of the Indians, creamy white bark, perhaps the hardiest of the white Birches. 6-8 feet, $\$ 1.00$.

\section{CATALPA-CATALPA.}

Catalpa speciosa, Western Catalfa. The most valuable species for Co'orado because of its hardiness, strong erect habit and rapid growth. It has attractive foliage and large panicles of exceedingly showy flowers, and is rarely injured by wind or snow or insects. The frequent substitution of inferior forms has detracted somewhat from the reputa. tion it deserves. Not suitable for altitudes above 6,000 feet. $6-8$ feet, 75 cents; 8-10 feet, $\$ 1.00$.

\section{CELTIS-HACKBERRY.}

Very hardy drought-resisting trees of Elm-like appearance.

Celtis occidentalis, Hackberry. A handsome tree with stout, spreading branches, light green foliage. 6-8 feet, 50 cents.

* Celtis reticulata, Western Hackberry. A native species, valuable for planting in dry or exposed situations where other trees will not thrive; in good soil it makes a compact tree of medium size and fairly rapid growth. 6-8 feet, 50 cents; 8-10 feet, 75 cents.

\section{CERCIS-JUDAS TREE.}

Cercis Canadensis, Judas Tree or RedBud. A small tree, producing a profusion of rose-pink flowers in early spring. Should have a sheltered location. 5-6 feet, 75 cents.

\section{CRATAEGUS-HAWTHORN.}

Ornamental trees of small size and dense growth, handsome foliage and showy flowers and fruit, they grow in almost any soil or position and for landscape planting they are of exceptional value.

* Crataegus Cerronis, Low and dense with small glossy foliage and red-brown fruit. 4-5 feet, 50 cents; $5-6$ feet, 75 cents.

*Crataegus Coloradensis, Colorado Haw. thorn. Flowers large, in ample clusters, fruit dark scarlet, abundant; leaves large. deeply cut; a small tree of fine apreaurance and ironclad hardiness. 2-3 feet, 50 cents.

Crataegus Oxyacantha, English Haw: thorn. Double flowered pink and double flowered white, either variety, 3-4 feet, 75 cents.

* Crataegus saligna, Black-fruited Hawthorn. A remarkably graceful tree of slender upright, almost fastigiate habit, small glossy foliage and black fruit. Twigs bright reddish brown, thorny; $3-4$ feet, 50 cents; 4-6 feet, 75 cents; 6-8 feet, $\$ 1.00$.

\section{ELAEAGNUS-OLEASTER}

Elaeagnus angustifolius, Russian Olive. Now recognized throughout the Plains reg. ion as one of our most valuable trees for ornament. Its beautiful silvery foliage and twigs its luxuriant graceful habit and abil. ity to resist all vicissitudes of climate, combine to render it distinct and indespensible. 5-6 feet, 50 cents.

\section{FRAXINUS-ASH.}

Trees of rapid growth, hardy, valuable for shade and for street planting.

Fraxinus Americana, White Ash. A handsome tree of upright symmetrical habit, making a clean thrifty growth. For street planting, shade and for parks it will easily rank among the best dozen trees for this climate. It is easily confused with the Green Ash, so that it is not well known here because the latter is much more abundant. The White Ash differs mainly in its more beautiful habit of growth. It stands the coldest winters here and in Denver without any injury whatever. 5-6 feet, 50 cents; $9-10$ feet, $\$ 1.00$.

Fraxinus lanceolata, Green Ash. Native of the northwest and considered hardier than the White Ash, making a desirable tree for the colder portions of our region. This is the Ash commonly grown in Colorado, but we strongly recommend the White Ash instead. 6-8 feet, 50 cents; 9-10 feet, $\$ 1.00$.

Fraxinus sambucifolia, Black Ash. A slender growing tree with straight smooth trunk and short spreading branches. 4-6 feet, 50 cents.

\section{GLEDITSIA-HONEY LOCUST.}

Gleditsia tricanthos, Honey Locust. This tree is often confused with the B'ack or Flowering Locust which belong to the genus Robinia. The latter has clusters of very showy flowers; the Honey Locust does not. Unlike the Black Locust, it never sprouts from the root and is never troubled by borers or other pests of any sort. It thrives perfectly throughout our region and has about the same rate of growth as the Soft Maple, yet is a long-lived hard wood tree. It is remarkably drought resisting and is undoubtedly the best tree for timber anu shade on "dry farms" and elsewhere. Small trees set a foot apart quickly form an im- 


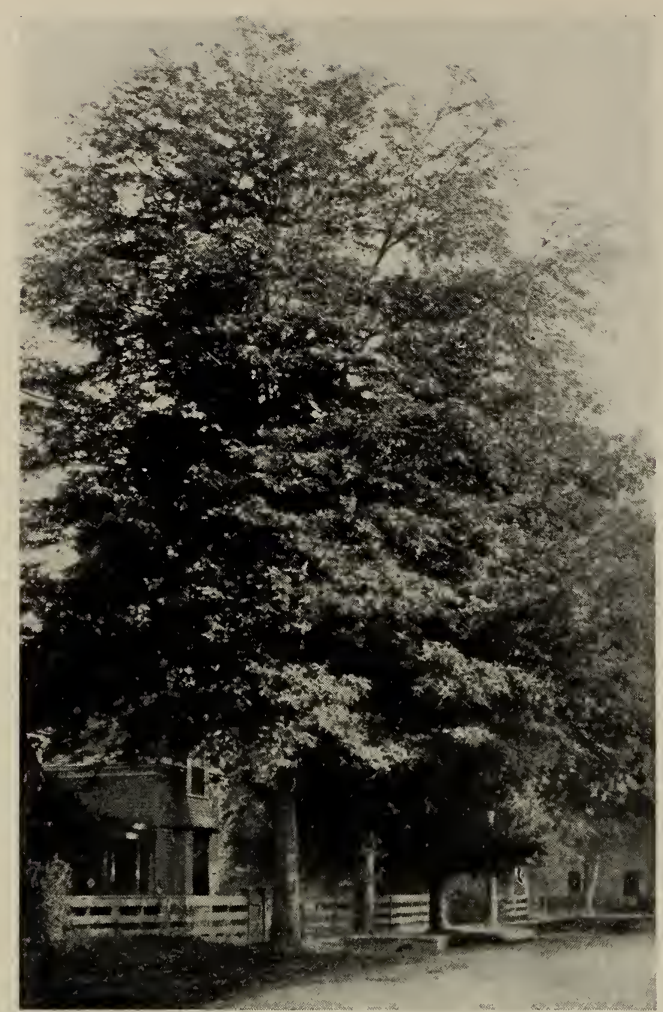

Thornless Honey Locust, (Gleditsia)

penetrable windbreak, and because of its deep-rooting habit it does not exhaust the soil like other trees commonly employed for this purpose. Very fine young seedlings, 1-2 feet, suitable for windbreaks and timber plantations, $\$ 3.00$ per hundred, $\$ 25.00$ per 1000 ; $8-10$ feet, $\$ 1.00$.

Gleditsia triacanthos inermis. Thorn. less Honey Locust. The thornless variety differs from the ordinary form in the absence of thorns. This eliminates the only objectionable feature and makes it the ideal shade and street tree. Its growth is very rapid and symmetrical, the tree beautifully proportioned, the trunk smooth and straight, the branching system perfect, forming a rather broad well rounded head, yet so strong as never to be broken by snow or wind. Foliage delicate and fern-like, casting a light shade, allowing grass to grow well underneath. It is uniformly healthy, requires little pruning, and without exception is the most valuable tree for this region. The cut shows a thornless tree growing in Boulder, 28 years old, 62 inches in circumference, measured four feet above the ground. Price of trees, $6-8$ feet, $\$ 1.00 ; 8-10$ feet, $\$ 1.25$; $10-12$ feet, $\$ 2.00$.
GYMNOCLADUS-COFFEE TREE.

Gymnocladus Canadensis, Kentucky Coffee Tree. Related to the Honey Locust and shares many of its good points; adapted to the same range but is of slower growtll. As an ornamental tree it is a favorite because of its unusually handsome foliage, and picturesque winter aspect. Deserves more general use. 5-6 feet, 75 cents; 6-8 feet, $\$ 1.00$.

\section{JUGLANS-WALNUT.}

Juglans cinerea, Butternut. Considered as hardy as the Black Walnut and has prov- $\Psi$ en fully as successful, though not as frequently planted. The nuts are of excellent quality and are produced in abundance where several trees are planted near together. 5-6 feet, 75 cents.

Juglans nigra, Black Walnut. A most valuable tree for timber, shade, and ornament, and one of the best nut trees for Colorado. Grows rapidly, is exceedingly hardy, thrives under a great variety of conditions. Every ranch in the state should have a grove of Black Walnut. 5-6 feet, 40 cents; 6-8 feet, 50 cents.

\section{MALUS-FLOWERING CRAB.}

Handsome small trees, literally covered in spring with showy sweet-scented flowers. Extremely hardy and thrive wherever an apple tree will grow. These rank among the most satisfactory of flowering trees, and present an attractive appearance throughout the season, and especially in their yellow and bronze autumn tints.

Malus coronarius. Wild Crab Apple. Forming a round symmetrical head, leaves broad, deeply serrate, flowers pink or rose, several in a cluster, fragrant. $3-4$ feet, 75 cents.

Malus Ioensis Bechtelii. Bechtel's Flowering Crab. A remarkably beautiful tree of small size and symmetrical form, often blooming while in the nursery rows. The flowers are perfectly double and resemble small roses both in form and delicate coloring, with true crab-apple fragrance. This charming variety has been developed from the Wild Crab of Minnesota and Iowa and is therefore extremely hardy and a gem among flowering trees. 3-4 feet, 75 cents; heavy seven foot specimens, $\$ 2.00$. This is all very fine stock.

\section{MORUS-MULBERRY.}

Morus Tartarica, Russian Mulberry. Valuable for windbreaks and for fence posts; as a single specimen it is very ornamental and the fruit is a great attraction to birds. 6-8 feet, 50 cents.

POPULUS-COTTONWOOD, POPLAR.

Hardy trees of very rapid growth, having considerable value because of their marvelous endurance of all sorts of conditions. They are short lived, and at best produce a very cheap effect. For city and town plant- 
ing they should be generally discarded wherever better kinds are practicable.

*Populus acuminata, Lance-leaved Poplar. A native, having the reputation of being the hardiest shade tree known for the extreme northern limits of our mountain region, and in my opinion, the best and most beautiful of all the species. It is characterized by lance-like foliage, smooth whitish bark, and rounded symmetrical head. This stock is propagated from a cottonless tree of unusual vigor. 8-10 feet, 75 cents; 10-12 feet, $\$ 1.00$.

Populus alba Bolleana, Bol?e's Poplar. A small pyramidal tree with striking silvery white foliage and green bark. 6-8 feet, 75 cents; 8-10 feet, $\$ 1.00$.

Populus Caroliniana, Carolina Poplar. I do not recommend this tree, believing it to be inferior to our native species.

Fopulus nigra fastigiata, Lombardy Poplar. Exceptional among all the trees suited to this region, because of its unique narrow columnar form of growth. It is therefore indispensable for the purposes to which it is adapted. 8-10 feet, 50 cents; $10-12$ feet, 75 cents; $16-18$ feet, $\$ 1.50$.

*Populus Sargentii. Common Western Cottonwood. Previously listed as Populus occidentalis. The best known and most widely planted shade tree of the eastern slope of the Rocky Mountains and plains. It is a more valuable tree than the Carolina Poplar which is to some extent superseding it. 6-8 feet, 35 cents; $10-12$ feet, 75 cents; $12-15$ feet, very stout, $\$ 1.50$ to $\$ 2.00$. Larger trees, $\$ 2.50$ to $\$ 5.00$ each.

PRUNUS-PLUM, CHERRY.

*Prunus Americana, Wild Plum. Of value for planting in thickets and in landscape work; very showy when in flower. 4-6 feet, 35 cents.

Prunus Padus, European Bird Cherry. In foliage and flowers this resembles the native Choke Cherry, but is more tree-like; an excellent small tree, attractive at all seasons, and hardy. 4-6 feet, 75 cents.

Prunus serotina, Black Cherry. A largo, growing shade tree, affording valuable timber. Showy racemes of fragrant white flowers and edible fruit. 5-6 feet, 75 cents.

For other species of Prunus, see shrubs.

\section{QUERCUS-THE OAKS.}

The Oaks may well be considered a synonym for strength and longevity. They are the most majestic and picturesque of all our forest trees. No landscape is complete without them, and fortunately there are species suited to every region where trees will grow. Oaks thrive in any soil but grow most rapidly in a deep moist loam.

They are seldom injured by the effects of climate, insects, or disease; and no othe: trees can compare with them in their gorg. eous autumn colors.

Quercus alba, White Oak. A majestic

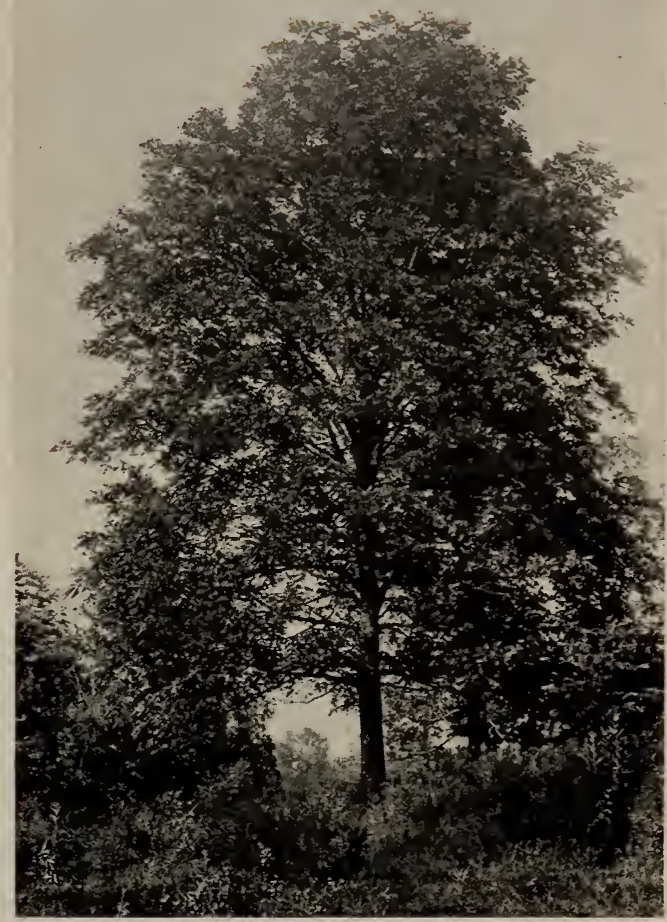

Black Walnut, (Juglans)

tree with broad rounded crown supported by massive branches. Beautiful lobed foliage, turning to wine-red in autumn, very persistent, often remaining on the branches through the winter. 2-3 feet, 50 cents.

Quercus macrocarpa, Burr Oak. One of the hardiest and a rapid grower in this climate. Branches stout, often corky, foliage deeply lobed, of leathery texture, acorns large, nearly enclosed in a mossy burr. 5-6 feet, $\$ 1.00$.

Quercus palustris, Pin Oak. A pyramidal tree with a single main trunk and horizontal or drooping branches; foliage finely cut, turning red and scarlet in autumn. Makes very graceful specimens and grows rapidly. 1.6 feet, $\$ 1.00$.

Quercus rubra, Red Oak. A large hand. some tree with a symmetrical, rounded, rather open crown, well supported by the smooth iron-gray branches and trunk. Foliage daik green, sharply cut, brilliant scarlet hues in autumn. When once established, this Oak has about the same rate of growth as the American Elm, and is an ideal shade tree, perhaps the best Oak for this region. 5-6 teet, $\$ 1.00 ; 6-8$ feet, $\$ 1.50$.

Quercus nana, Scrub Oak. A small shrubby species with handsome foliage. 3-4 reet, 75 cents. 


\section{ROBINIA-FLOWERING LOCUSTS.}

These are not to be confused with the Honey Locust, for which see Gleditsia.

* Robinia Neo-Mexicana, Rocky Mountain or Pink Flowering Locust. A hardy native tree, in general appearance like the Black Locust but of smaller size, and flowers a beautiful shade of rose pink. 6-8 feet, $\$ 1.25$.

Robinia pseudacacia, Black Locust. Va:ued for its durable timber, and a satisfactory shade and ornamental tree. Its drooping racemes of yellowish white flowers are delightfully fragrant and very showy. 6-S feet, 50 cents.

Robinia pseudacacia Bessoniana, Thornless Black Locust. This variety has very short prickles on the new branches which soon disappear. The stock has been propagated from one original tree so that for with dark green shining foliage; splendid as a specimen on the lawn. 6-8 feet, 75 cents.

\section{SORBUS-MOUNTAIN ASH.}

Sorbus Americana, American Mountain Asb. Usually shrub-like, but sometimes becoming a tree. It is quite different from the European Mountain Ash, more nearly resembling jur Colorado srecies, but thrives better in cultivation. It is perfectly hardy and shculd rank as one of the very best large shrubs. 4-5 feet, 75 cents.

Sorbus aucuparia, European Mountain Ash. For creating a charming lawn effect no tree is more appropriate. Of medium size, graceful and symmetrica!, showy both in flower and fruit, healthy and vigorous; it wins greater popularity nach season. 6-8 feet, 75 cents.

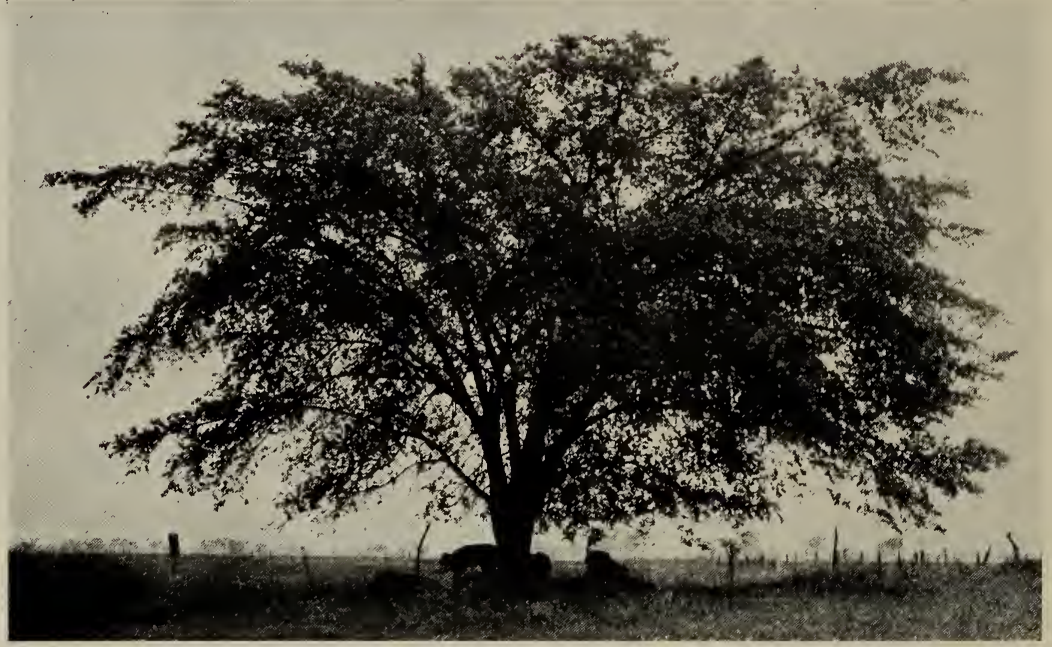

American Elm, (Ulmus Americana). Page 9.

avenue planting they make perfectly uniform specimens which gives a fine effect. 6-8 feet, 75 cents; 8-10 feet, $\$ 1 . v 0$.

\section{SALIX-WILLOWS.}

Hardy trees or shrubs of rapid growth, unusually tollerant of moisture. The following kinds are recommended for ornamental planting:

Salix aurea, Russian Golden Willow. A quick-growing tree of extreme hardiness, notable for its yellow branches which are particularly effective during t.e winter. 6- $\delta$ feet, 50 cents.

Salix, Niobe Weeping Willow. The hardiest and finest weeping willow, brought from Siberia by Prof. Hansen of Dakoia; bright yellow bark. 6-8 feet, 75 cents.

Salix pentandra, Laurel-leaf Willow. A handsome pyramidal tree of medium size,

\section{TILIA-LINDEN.}

The Lindens are choice and desirable shade trees, well suited to this region. Thes: are healthy, hardy and not troubled by ils sects. All kinds bear fragrant, creamy white flowers in great prufusion.

Tilia Americana, American Linden or Basswood. A large tree with spreading branches, heart shaped foliage, affording a 10.06 dense shade; suitable for streets, lawns or parks. $5-6$ feet, 75 cents; 6-8 feet, $\$ 1.00$.

Tilia Europea, European Linden. A large tree of symmetrical growth, less spreading than the American Linden and with smaller foliage; one of the finest deciduous trees for lawn planting and excellent for avenues. 5-6 feet, 75 cents.

Tilia platyphyllos, Large-leaved Linden. A large and stately tree with a handsome pyramidal crown, or with age becoming 
round-topped and massive. The largest of the European Lindens. 5-6 feet, 75 cents.

\section{ULMUS-THE ELMS.}

The elms, whose graceful outlines and artistic proportions are the delight of the tree lover, are not at their best in this region yet their hardiness and general adaptability to all soils and conditions render them fai more valuable than many other trees. Their chief defect is their tendency to lean from the wind in exposed places. This tendency will be offset to a large degree in park and city planting where they can have ample protection by other trees or buildings.

Ulumus Americana, American or White Elm. This is without doubt the most popular tree in America. Of large size and rapid growth; exceedingly variable in habit, sometimes upright, or often broadly spreading as shown in the cut. It is therefore more suitable for shade and far parks than for avenues. Our stock is the finest that can be grown. 6-8 feet, 50 cents; 8-10 feet, 75 cents.

Ulmus campestris, English Elm. The ordinary form has small dark green leaves, more or less corky twigs, and rather comract, upright growth. 6-8 feet, $\$ 1.00$.

UImus scabra, Scotch or Wych Elm. A large tree of rather dense growth, forming a rather broad rounded crown. Like all the European Elms, its foliage remains green very late in the season. $6-8$ feet, $\$ 1.00$.

UImus scabra Dovaei, Dovey's Scotch Elm. A distinct variety of vigorous growth and upright pyramidal habit. 7-8 feet, $\$ 1.50$.

Ulmus scabra pendula, Camperdown Weeping Elm. A weeping variety grafted on straight stems 6 to 8 feet high, producing a dense canopy of luxuriant foliage. 2-year heads, $\$ 1.50$.

\section{COLORADO EVERGREENS}

Evergreens in winter lend the fullest expression of our joy in a luxuriance of green foliage, and extend good cheer through the season when it is most needed.

They are the dominating feature of our native vegetation, and for planting about the home, on the farm and in parks and semi-public grounds, their value to a community can scarcely be estimated.

The native evergreens of Colorado are justly famed as the most beautiful in the world and are everywhere highly esteemed. They are preeminently the most suitable for planting in this climate, thriving as only natives can thrive, while only a few exotic sorts can be depended upon.

A general impression exists that evergreens are difficult to transplant and slow of growth. Most failures in either respect arise from a misapprehension of simple requirements. When evergreens are to be transplanted, they should be dug with a ball of the original soil enclosing the roots. This should be securely wrapped and kept moist until replanted. Trees from the nursery handled in this way should sustain no loss whatever in replanting, and medium sized speciments dug directly from the mountain sides will be nearly as successful.

The best time for planting is in spring before growth begins. Trees in the mountains start later than those in the nursery, and can be, and usually are, shipped after the nursery trees are too far advanced for transplanting. If in a sufficiently retarded condition they may be planted safely as late as June.

The rapidity of growth varies greatly with conditions. The pines, Junipers and Red Spruce require little moisture; will exist on less than sufficient to support any deciduous trees, yet all these make their best growth with an abundance of moisture, if attended with good drainage. Under favorable conditions, the Bull Pine, Blue Spruce and Red Spruce will make an average growth of one to one and one-half feet annually, and the other sorts will do nearly as well.

Evergreens should be planted very firmly, tamping the soil thoroughly around the ball but leaving the surface loose. A void too much water as carefully as too little. Over-watering or too frequent watering is most detrimental on retentive clay soils. Water thoroughly and then withhold until more is needed. The danger period with recently planted evergreens is during late July, August and September. At this time they are forming the buds which determine the growth of the next season, and the same care in watering and cultivation should be continued until the growth is entirely matured. 
The best care in planting cannot offset the need of good stock to start with. In no other class of nursery stock does quality and skillful preparation count for as much. The "Rockmont method" of handling evergreens is the result of years of practical experience, and proves uniformly successful because based on scientific principles.

All the following evergreens are grown in our nursery and several times transplanted to produce an abundance of fiberous roots, unless otherwise stated.

Colorado native sorts are indicated by an asterisk (*).

LARGE EVERGREENS. I have long made a specialty of supplying evergreens collected directly from the mountains, all of which are dug and shipped with a solid ball of earth enclosing the roots, which practically insures success if followed by proper planting and subsequent care as described above. Larger sizes can be furnished than I have in the nursery and this means a gain of several years time. While there is of course a limit to the sizes whicn can be practicably handled, it remains to some extent a question of cost, which increases accorōing to the additional care and expense necessitated in safely handling the larger sizes. Correspondence is invited with all who are interested now or for future requirements, and I feel safe in promising the highest possible quality of service at very moderate prices.

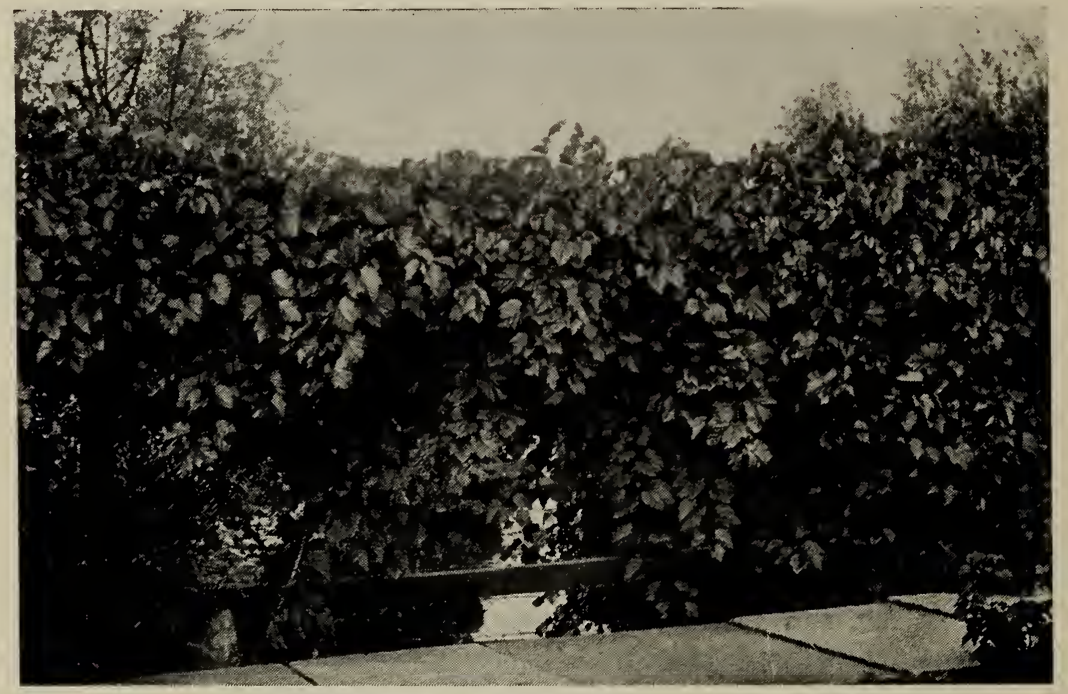

Wild Grape (Vitis vulpina) on wire fence. See page 13.

JUNIPERUS-JUNIPER, CEDAR.

*Juniperus scopulorum, Colorado Silver Cedar. A near relative of the Virginia Red Cedar, but with some important differences. In form it is of narrower, more upright growth, very compact and symmetrical, and the foliage has the beautiful silvery effect which is characteristic of many of the Colorado evergreens. It retains its lower branches and symmetrical form to a great age, and its silvery green color well through the winter. In Colorado it is at present the most popular of all evergreens. $1 \frac{1 / 2-2}{\text { feet, }}$ 50 cents; $2-21 / 2,75$ cents; $21 / 2-3$ feet, $\$ 1.00$. Larger sizes collected to order.

*Juniperus Siberica, Prostrate Juniper. A low creeping evergreen, its graceful sprays spreading fan-like in all directions.
10-12 inch clumps, 50 cents; 2 foot clumps, $\$ 1.00$.

PICEA-SPRUCE.

*Picea Engelmanii, Englemann's Spruce. A fine large growing species of very symmetrical form, branches, ascending, foliage blue-tinged but not as silvery as the Blue Spruce. 1-2 feet, 75 cents.

*Picea pungens, Colorado Blue Spruce. A symmetrical tree with horizontal or slightly ascending branches, needles very stiff and sharp pointed, foliage varying from nearly green to silvery blue. The color usually improving under cultivation, but not reaching its best for a year or two after transplanting. The state tree of Colorado, and found native only in Colorado, Wyoming and Utah. It has gained a most 
remarkable popularity throughout America and Europe, combining as it does superlative beauty with almost universal adaptability. Ordinary forms more or less tinged blue, $1-11 / 2$ feet, 50 cents; $11 / 2-2$ feet, 75 cents; $2-21 / 2$ feet, $\$ 1.00 ; 21 / 2-3$ feet, $\$ 1.50$; $3-4$ feet, $\$ 2.50$. Larger sizes collected to order.

Picea pungens glauca, Extra silver-blue. $1-11 / 2$ feet, $\$ 1.00 ; 11 / 2-2$ feet, $\$ 1.50 ; 2-21 / 2$ feet, $\$ 2.50$. Larger sizes collected to order.

Picea pungens, Koster's, having not only the finest silver-blue color, but also much denser foliage. Grafted specımens from Koster's famous variety. $1 \frac{1}{2}-2$ feet, $\$ 3.00$. PINUS-THE PINES.

The value of the Pines for cultivation has not been fully appreciated. They are considered difficult to transplant, but this is not the case when handled by our improved method. No other windbreak is so effective, and for park and home planting the shelter they afford to other vegetation is worth considering, aside from their high ornamental value.

*Pinus flexilis, Rocky Mountain White or Limber Pine. Soft bluish green fo!iage; a slender tree while young, very picturesque when old. 1-2 feet, 75 cents.

Pinus montana, European Rock Pine. A hardy, short-leaved Pine, of comparative- ly rapid growth; our stock is extra fine. $2 \cdot 3$ feet, $\$ 1.00$

*Pinus Murryana, Lodgepole Pine. Rather short light green foliage; a slender tree of symmetrical spruce-like habit, growing rapidly in a moist sandy loam. Collected $11 / 2-2$ feet, 75 cents; $2-3$ feet, $\$ 1.25$.

*Pinus scopulorum, Rock or Bull Pine. The common Pine of our foothills, and one of the most noble and picturesque of American conifers. The most valuable Pine for planting in this region and will succeed throughout the state with very little moisture when once established. This will doubtless prove to be the best evergreen for "dry farming" and as a windbreak will be found effective in conserving moisture. $2-21 / 2$ feet, $\$ 1.00$; collected $1 \frac{1 / 2}{-2}$ feet, 50 cents, $\$ 35.00$ per hundred; $2-21 / 2$ feet, 75 cents.

PSEUDOTSUGA-RED SPRUCE.

- Pseudotsuga Douglasi, Douglas or Red Spruce. The common Spruce growing on dry north slopes; a handsome tree in cultivation, and extensively used in Europe for forest planting. Collected 1-2 feet, 50 cents; 2-3 feet, 75 cents.

For other evergreen shrubs, vines and perennials, refer to Berberis aquifolium, Berberis repens, Euonymus radicans, Euonymus radicans variegata, English Ivy, Vinca minor, Yucca filamentosa and Yucca glauca.

\section{VINES AND CLIMBERS}

No planting scheme for the home is complete without vines. They eliminate stiffness, cover bare walls and arbors, make effective screens, and convert unsightly objects into bowers of beauty.

The kinds available for this climate afford ample opportunities for the manifestation of good taste in their selection and arrangement. Plant vines in abundance, see that they have sufficient depth of good, fertile soil, and do not neglect them. Too often they are planted in a mixture of sub-soil, brickbats and building refuse; their success is of sufficient importance to warrant liberal attention to their simple requirements.

Ampelopsis Engelmanni, Engelmann Ivy. For Colorado this is without exception the best vine for covering brick or stone wa!ls, upon which it climbs and clings firmly by means of disc-bearing tendrils, requiring no other support. It grows rapidly and is entirely hardy and thrives under many conditions, growing equally well on either north or south exposures. It is a vine of neat appearance, thrifty and healthy, more slender and with smaller foliage than the native Woodbine; the leaves are five-parted, and in autumn assume most brilliant hues of red and crimson. It is also suitable for arbors and trellises, and may be allowed to climb the trunks of large trees without injury. Strong vines, 25 cents, $\$ 17.50$ per 100 .

*Ampelopsis vitacea, Native Woodbine. An exceedingly hardy and vigorous vine, climbing by tendrils and will climb rapidly and extensively upon netting or other support. Strong vines 25 cents.
Ampelopsis Veitchii, Boston Ivy. This is a beautiful vine with three-parted foliage, clings to brick or stone, but is not as rapid growing nor as hardy as the Engelmann Ivy. Strong plants, 35 cents.

*Apios tuberosa, Ground-nut. A hardy herbaceous vine which grows up from the root year after year, making a rapid and dense growth, producing clusters of small chocolate-purple flowers. One of the few vines that can be depended upon to make an effective screen the first season. The best support is poultry wire, and the tubers should be planted six to twelve inches apart; 15 cents. $\$ 8.00$ per hundred.

Aristolachia Sipho, Dutchman's Pipe. A magnificent vine for porches, the very large, heart-shaped leaves making a dense shade. 50 cents.

Bignonia radicans, Trumpet Creeper. Very showy orange red, trumpet-shaped flowers. 25 cents. 
Celastrus scandens, American Bittersweet. A twining woody vine with remarkably showy fruits which in this climate remain a bright vermillion red all winter. 25 cents.

Clematis coccinea, Scarlet Clematis. An herbaceous vine, coming up from the ground each season, growing rapidly and producing in constant succession from June till frost, bright scarlet, bell-shaped flowers, followed by seed plumes which remain till winter. 25 cents.

Clematis crispa, very similar, but flowers lavender or purple, fragrant. 25 cents.

*Clematis ligusticifolia, Western Virgin's Bower. A hardy graceful climber of vig. orous and rapid growth, affording a dense a tree trunk or wall, but does best planted with Engelmann's Ivy which it will use for a support and thus climb to a considerab'e height, clothing the latter with green foliage all winter. This is the vine shown on front cover of this catalogue. 2 year old, 25 cents, $\$ 18.00$ per 100 ; large clumps 50 cents.

Euonymus radicans variegata. A variety with the foliage beautifully variegated with creamy white. Fully as hardy and useful as a ground trailer but shows little disposition to climb. 25 cents.

Hedera helix, English Ivy This is a grand evergreen climber, and has proven entirely hardy on north walls if protected from severe winds; beautiful when grow-

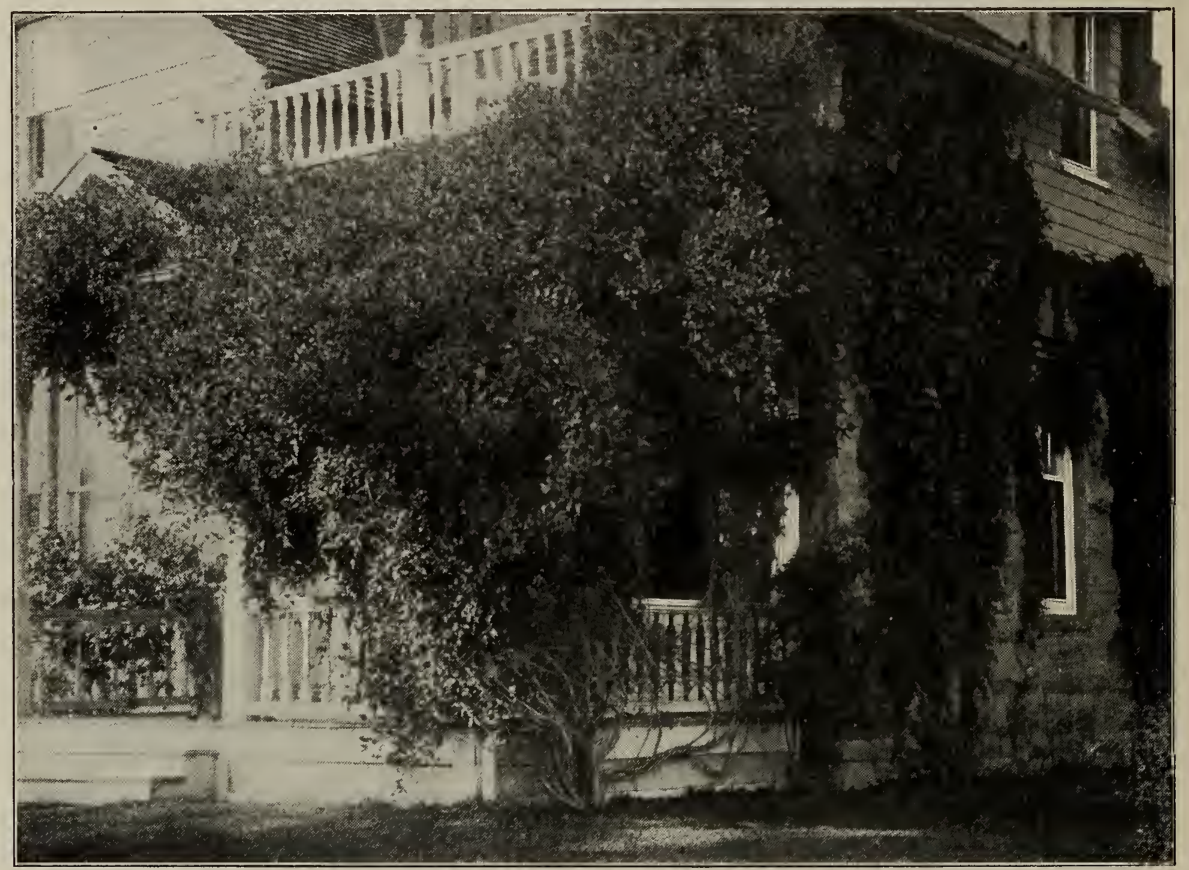

Clematis ligusticifolia frowing over porch.

shade; this is the vine covering the porch in our photograph. The flowers resemble those of C. paniculata, and are followed by very conspicuous seed plumes. 25 and 35 cents.

Clematis paniculata, Japanese Clematis. One of our hardiest and most, valuab'e climbers, the dark glossy foliage affording a dense shade; the clusters of fragrant white flowers are borne in such profusion as to nearly hide the foliage for weeks. Strong roots, 25 and 35 cents.

Euonymus radicans. This may be used as a substitute for English Ivy, where the latter is not hardy; it is the hardiest evergreen vine in cultivation. It will cling to ing upon the trunk of a large tree; requires no fastening or support. Strong vines 25 cents.

*Humulus lupulus Neo-Mexicana, Rocky Mountain Hop Vine. This is so much better than the common Hop Vine, having larger and more handsomely cut foliage, that we grow it exclusively. It is a luxuriant climber, making a good growth the same season it is planted, and althoug, dying to the ground each winter it comes up stronger each successive spring, affording an early and effective shade. 25 lents.

Lonicera aurea reticulata, Golden Variegated Honeysuckle. Valued for its beautiful foliage which is attractive all the sea- 
son; leaves green, elegantly veined and reticulated with golden yellow. Strong plants, 35 cents.

Lonicera Halleana, Hall's Fragrant Japanese Honeysuckle. Nearly evergreen foliage, flowers white, turning yellow, delicious ly fragrant. Strong vines, 35 cents.

Lonicera sempervirens, Scarlet Trumpet Honeysuckle. Flowers scarlet blooming all summer, coral-red berries. Strong vines, 35 cents.

Lonicera sempervirens flava, Golden Trumpet Honeysuckle. A most charming variety with golden-yellow trumpets, otherwise the same as the last. Strong vines, 35 cents.

Lycium barbatum, Matrimony Vine. 25 cents; see shrubs for description.

Vinca minor, Periwinkle, Myrtle. A well known trailing evergreen plant, valu- able for covering ground anywhere, and especially in places too shady for grasses or other plants to thrive; will succeed in any soil and dry places. 15 cents, $\$ 6.00$ per 100.

Vitis vulpina, Wild Grape Vine. Valuable for covering arbors, fences or anything where a luxuriant growth of foliage is desired. The flowers are deliciously fragrant and the small black grapes are not unattractive. Our illustration shows the Wild Grape growing on a wire fence. 3-year-old vines, 25 cents, $\$ 15.00$ per 100 .

Wisteria Frutescens, American purple Wisteria. The hardiest and best sort for this climate; a grand vine with showy flowers, and needs a rich loamy soil for best development. 25 and 50 cents.

Wisteria Frutescens alba, White Wisteria. Same as the last, but flowers pure white. 50 cents.

\section{HEDGE PLANTS}

A well grown and well kept hedge is an acquisition of which any property owner may be justly proud. One of the prime requisites of a formal or trimmed hedge is hardiness. The California Privet is used in the East and South for formal hedges more than any other plant, but in Colorado it is not sufficiently hardy. However, there are several kinds of Privet suitab!e for hedges, and for Colorado the best and hardiest is the European Privet, Ligustrum vulgare. A hedge of this kind is shown in our illustration, reproduced from a photograph of one of the first hedges planted in Boulder.

A successful hedge requires thorough preparation. There should be sufficient depth of good soil, and if the native soil be poor, it should be excavated about 18 inches in depth and width, and the trench filled with good soil with which should be mixed one-tenth to one-fifth of very old barnyard manure. Unless old manure can be obtained use most of it for a top-dressing instead of mixing with the soil. In all cases where the soil is very light or sandy most of the manure should be used as a mulch or top-dressing, as if mixed with the soil it will dry out too rapidly.

Most hedge plants should be set in a single row, only slightly deeper than they grow in the nursery. With the European Privet we make an exception and set it four to six inches deeper, partly covering the lower branches which in time will take root, making the hedge very dense at the bottom. The plants should be spaced eight or nine inches apart, so 100 feet of row will require 135 to 150 plants. In planting pack the earth firmly about the roots but leave the surface loose and keep it mellow throughout the season.

After planting, trim to a uniform height of six or eight inches. No further pruning is advised the first season, but early the second spring cut back again to about three inches higher, and again whenever about one foot of new growth has been made, allowing an advance of only two or three inches each time until the required height is attained. This produces a finer and denser growth than when allowed to grow up too rapidly.

A depression along the upper side of the row will aid in watering. A tholough watering not oftener than every ten days or two weeks which will wet the soil to the bottom of the trench is very much better than a daily sprinkling. If at any time during the season the plants do not seem to be doing well, dig down at the side of the row and if the soil at a foot deep is dry it will indicate insufficient watering. On 


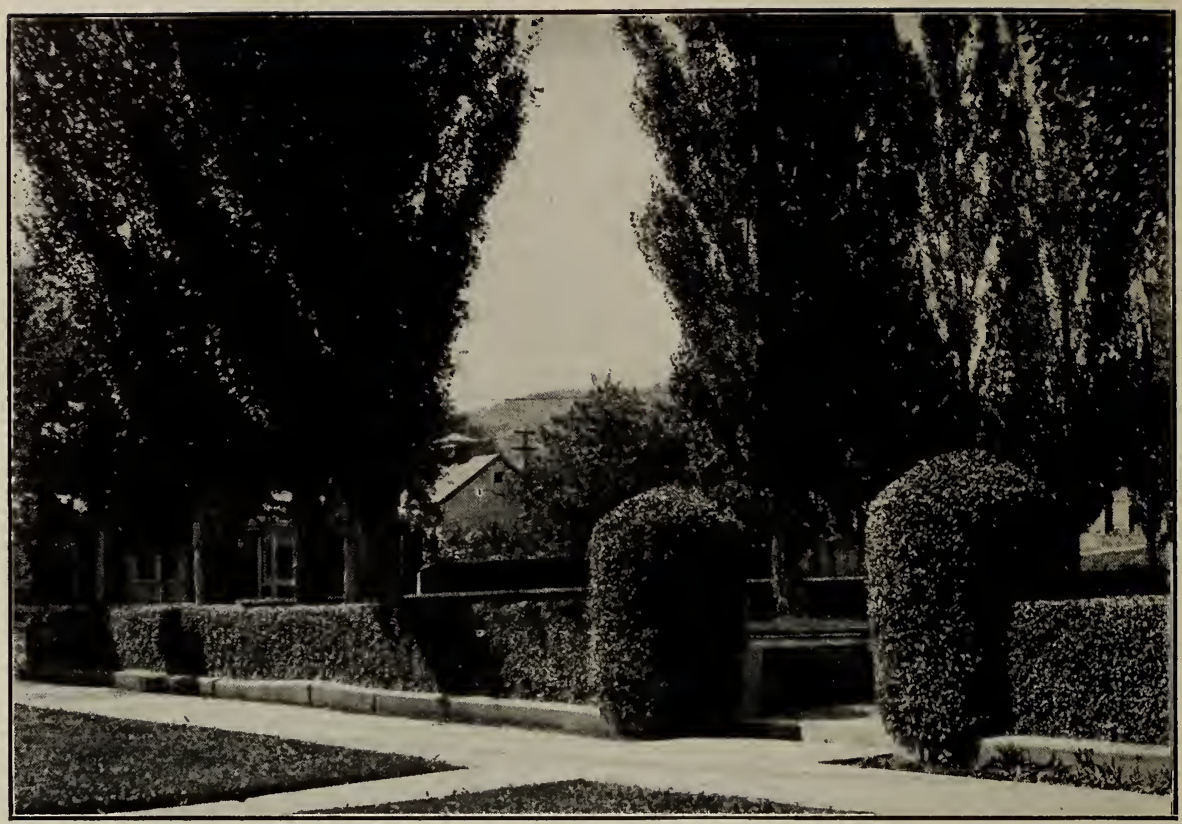

Hedge of European Privet (Iigustrum vulgare), page 15.

th; other hand, if found saturated, the surface soil along the row should be loosened and water withheld until the plants revive. Too much or insufficient watering is about the only reason for failure with European Privet after it is properly planted. It is probably unnecessary to say, that alkali in the soil is detrimental to nearly all shrups and plants, and to some kinds much more than others. The Privet will endure but very little. If you wish to plant a hedge and suspect that your soil contains alkali, describe your conditions and just what sort of a hedge or screen you desire and let me advise you what to plant. I would suggest sending by mail an ounce or two of your soil and I will test it for you free of charge.

A more complete description of the following hedge plants will be found under "Deciduous Shrubs."

Berberis Thunbergii, Japanese Barbery. Makes a spreading, informal hedge not to exceed three or four feet in height and breadth, and needs but little clipping to keep it sufficiently uniform. Distance for planting 12 to 18 inches. Per 100, 1-1 1/2 feet, $\$ 8.00$.

Berberis vulgaris, Common Barberry. Grows taller and less spreading than the Japanese Barberry; will reach six or seven feet under favorable conditions. Plant 12 to 14 inches apart in the row. Per $100,1 \frac{1}{2}$ to 2 feet, $\$ 8.00$.

Berberis vulgaris atropurpurea, Purpleleaved Barberry. In all respects the same as the green variety except that the foliage is a beautiful dark purple. Per $100,11 \frac{1}{2}-2$ feet, $\$ 8.00$.

Caragana arborescens, Siberian Pea Shrub. A tall shrub, slightly spiny, of very erect habit of growth, sufficiently hardy for North Dakota and Minnesota, and will make a very dense hedge or screen which will grow eight or ten feet tall but can easily be kept much lower if desired; distance for planting, one foot. Per 100, 2-3 feet, $\$ 12.00$.

Caragana Chamlagu, A very dwarf kind from North China, entirely hardy, and is nearly evergreen, the small glossy leaves retaining their freshness till December and the lower ones all winter. This is only recommended for a hedge or edging one foot high or less, setting the plants six to eight inches apart. Per $100 \$ 12.00$

Cydonia Japonica, Japan Quince. A very successful flowering hedge; is sufficiently thorny to afford some protection, will stand considerable trimming but should be allowed to make a natural growth. Will grow four to six feet tall and should be planted 12 to 24 inches apart. Per $100,1 \frac{112-2}{2}$ feet, $\$ 10.00$.

Eleagnus angustifolius, Russian Olive. Although this ranks as a tree of considerable size, it may, by systematic shearing, be trained and kept as a formal hedge of mcterate dimensions, or if allowed to grow 
tall will make an effective and ornamental wind-break or screen. It is absolutely hardy. will stand considerable alkali, and the branches are thorny enough to make a barrier against stock; distance for planting, 12 to 24 inches. Per $100,1 \frac{1}{2}-2$ feet, $\$ 8.00$.

Gleditsia triacanthos, Honey Locust. Sometimes planted for a defensive hedge and also for windbreaks; it should be set close, about 12 to 18 inches or even closer Per $100,1-2$ feet, $\$ 3.00$.

Ligustrum Regelianum. This should not be sheared, but allowed to make an informal growth like the Japanese Barberry; it is however a larger shrub and should be planted about two feet apart. Per 100, 11/22 feet, $\$ 12.00$.

Ligustrum vulgare, European Privet. See illustration at the head of this division. As previously stated, I consider this the best plant for a formal hedge. For full planting instructions, see the beginning of this division. I have a large stock of the plants. Per $100,1 \frac{1}{2}-2$ feet,$\$ 5.00$.

Lonicera tartarica alba, Lilac, Spiraea Van Houttei are flowering shrubs which may be used as hedges or screens, and Rhamnus or Buckthorn is used as a defensive hedge. Several of the native evergreens and Hawthorn may be used as screens, or backgrounds for other planting.

\section{DECIDUOUS SHRUBS}

The judicious planting of shrubs adds greatly to the beauty and value of property, and contributes a wealth of pleasure and interest to the home. A good arrangement of shrubs invariably provides wide open stretches near the center of the lawn, and the partial concealment of the sharp lines of boundaries and buildings will often increase the apparent dimensions of the premises. Large shrubs and small trees can be arranged to effectively screen objectionable views, and at the same time create an air of seclusion for the home.

I invite particular attention to the large variety of native shrubs offered in this list. Ones first impression in planting shrubs is to reject the native material because he sees no point in cultivating what grows wild all about him. While $I$ believe in and advocate the liberal use of the best plants which other countries have to offer, I would consistently stand for the relatively greater value of Colorado evergreens and shrubs for Colorado conditions. The natives grow better, are hardier, healthier, and cost less to maintain. We can never get the utmost luxuriance unless we make the native plants dominant. In propagating the native plants, it is my practice, as far as possible, to handle only the most desirable or improved types.

Colorado native plants are indicated by an asterisk (*).

* Amorpha canescens, Lead Plant. Silvery foliage, purple flower spikes, 25 cents each.

*Amorpha fruitcosa, Wild Indigo Shrub, Locust-like foliage, dark purple flowers in slender spikes. 2-3 feet, 25 cents.

*Amorpha nana, Sweet Indigo. A very dwarf shrub, not exceeding two feet, with minute foliage, numerous spikes of dark garnet- rose flowers: whole plant agreeabiy scented. 1-2 feet, 50 cents.

Aralia spinosa, Hercules Club. A very luxuriant shrub with large bi-pinnate leaves of tropical appearance; upright spiny stems, panicles of white flowers, $2-3$ feet 35 cents.

Aralia pentaphylla, a handsome species with dark green foliage resembling the Engelmann Ivy or Virginia Creeper. 2-3 feet, 35 cents.

Berberis Aquifolium, Holly-leaved Barberry. An evergreen shrub resembling our native Oregon Grape, but of larger growth, reaching $2-3$ feet; 1 foot, clumps, 25 cents.

"Berberis Fendleri, Rocky Mountain Bar- berry. A native of southern Colorado, but perfectly hardy: Resembles B. Thunbergii, but more upright and the berries growing in clusters, bright scarlet, very persistent, flowers yellow. Often bears so heavily that the branches droop with the weight of fruit, and is perhaps the most beautiful berried shrub in cultivation. 1-2 feet, 35 cents; 2-3 feet, 50 cents.

*Berberis repens, Oregon Grape. An evergreen ground-covering plant with foliage like Holly; flowers fragrant, bright yellow, berries blue. $\$ 1.00$ per dozen, $\$ 5.00$ per hundred.

Berberis Thunbergii, Japan Barberry. A graceful small shrub of dense habit, leaves small, bright green, turning in autumn to the most dazzling tones of orange, scarlet and crimson. Berries scarlet, persisting throughout the winter. One of the most beautiful shrubs in cultivation. $1 \frac{1}{2}-2$ feet, bushy, 25 cents; 2-3 feet, 35 and 50 cents.

Berberis vulgaris, Common Barberry. A most graceful shrub, growing 4-6 feet, bristly- 
toothed foliage, racemes of showy yellow flowers followed by the scarlet berries which remain until late in the winter. 2-3 feet, 25 cents.

Eerberis vulgaris atropurpurea. Purple Barberry. A striking variety with deep purple foliage. The most satisfactory darkleaved shrub. 2-3 feet, 25 cents.

Caragana arborescens, Siberian Pea Shrub. A handsome, erect shrub with pinnate foliage, and clusters of yellow peashaped blossoms in spring and early summer; neat and very hardy. 2-3 feet, heavy stock, 25 cents; large, 35 and 50 cents.

Caragana Chamlagu, Chinese Pea Shrub. A small shrub that will always remain small is often indispensable for landscape planting, and this one is usually good, probably never exceeding 2 feet in height. The habit is spreading and graceful. It is entirely hardy, nearly evergreen, usually retaining some of its glossy green leaves all winter. Flowers pea-shaped and quite showy. This is such a splendid thing that I am growing a large stock. 1-2 feet, strong, 25 cents, $\$ 12.00$ per 100 .

Cephalanthus occidentalis, Button Bush. A vigorous growing shrub about 4-6 fett tall, of bushy habit, large glossy foliage, round flower heads an inch in diameter, creamy white, fragrant. 2-3 feet, 25 cents.

*Cercocarpus parvifolius, Mountain Mahogany. A curious small-leaved shrub with long wand-like branches, bearing during the summer numerous feathery-tailed seeds, producing a most unique effect. 2-3 feet, 25 cents; $3-4$ feet, 35 cents.

Colutea arborescens, Bladder Senna. A bushy shrub with pinnate foliage, yellow pea. shaped flowers and large inflated pods; blooms all summer. 2-3 feet, 25 cents; $3-4$ feet, 35 cents.

Cornus paniculata, Free-flowering, very handsome when in bloom, clusters of white fruits on red peduncles in the summer and fall. 3-4 feet, 35 cents.

*Cornus stolonifera Coloradensis, Co'orado Red-stemmed Dogwood. This differs from the eastern form in several essential particulars and is undoubtedly the better shrub of the two. It is a very handsome spiecies of upright growth with deep red branches and gray-green foliage. It blooms nearly all summer and the pearly berries in clusters are very pretty. The fall color of the foliage and the winter color of the twigs are unequalled. 2-3 feet, 35 cents.

Cornus stolonifera lutea, Yellow-stemmed Dogwood or Osier. A handsome variety with bright yellow branches, very effective when planted with other sorts. 2-3 feet, 35 cents.

Cornus Siberica, Siberian Dogwood. This differs from the Colorado Dogwood in larger foliage and brighter twigs which are a shade lighter. It has the brightest red

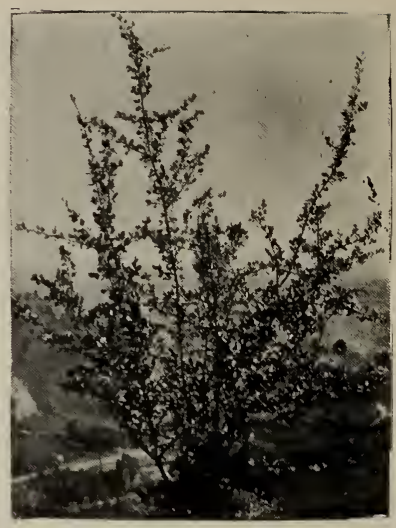

Cercocarpus Parvifolius.

bark of any shrub, is hardy and always satisfactory. 2-3 feet, 25 cents.

*Corylus rostrata, Hazelnut. Valuable for producing dense thickets; handsome foliage and interesting burrs containing small edible nuts. 2-3 feet, 25 cents.

Cydonia Japonica, Flowering or Japan Quince. Early-flowering spiny shrubs; flowers vermilion-scarlet, fruit about two inches in diameter, aromatic-fragrant. 3-4 feet, 35 cents.

Desmodium penduliflorum, see Lespedeza under Herbaceous Perennials.

Elaeagnus longipes, Silver Thorn. A hardy shrub related to the Russian Olive, having beautiful silvery foliage and red berries. 1-2 feet, 35 cents.

Euonymus alatus, Cork-barked Wahoo or Burning Bush. A native of Japan with corky twigs, small red berries, foliage turning in autumn to a peculiar shade of rose-crimson. 50 cents.

Euonymus Europeus, Burning Bush or Strawberry Tree. A large shrub, 6-8 feet or larger, leaves large dark green, fruit four-lobed, rose pink, opening and disclosing the orange-coated seeds; branches green or purplish, often cork-winged. 2-3 feet, 25 cents; $3-4$ feet, 35 cents; very heavy clumps 75 cents.

Flowering Almond. See Prunus Japonica.

Forsythia Fortunei, Golden Bells. A vig. orous upright bush with slender arching branches; flowers pale yellow, appearing in great profusion before the leaves. 2-3 feet, 25 cents.

Forsythia viridissima, Dark green Forsythia. This has proven by far the hardiest Forsythia in our nursery, standing 20 below zero without winter killing. It is of rather compact habit, : foliage very deep green, branches green all winter; not as tall as Fortunei, flowers similar and appearing at 
the same season. 1-2 feet, 20 cents; heavy clumps, 50 cents.

Hippophae rhamnoides, Sea Buckthorn. A large shrub of informal habit of growth, exceedingly hardy; leaves gray above, silvery-white underneath, the branches also si.ver-coated in the winter. The flowers are yellow and the berries orange-red. It thrives unusually well in this climate and altogether promises to be one of our most valuable large-growing shrubs. 3-5 feet, 35 cents; 5-6 feet, 50 cents.

*Holodiscus dumosus, Wild Spiraea. One of our most charming native shrubs, form. ing graceful clumps with slender arching branches, each terminating in an airy plume cf creamy white or pink tinted flowers, which change so little in going to seed that the bush has the appearance of remaining in boom for months. The northern Colorado plant is hardy north, while the southern forms are not. Clumps, 3-4 feet, 75 cents.

* Jamesia Americana, Wild Mock Orange. A low bush with velvety foliage, clusters of waxy white flowers which are delightfully fragrant and resemble Orange blossoms. Clumps, $11 / 2-2$ feet, 35 cents.

Ligustrum Ibota, Japanese Privet. Much used in landscape planting for its graceful habit and clusters of small iragrant flowers followed by black fruit; " used also for hedges. 2-3 feet, 25 cents.

Ligustrum Regelianum. Considered a variety of Ibota and equally hardy; differs in its more spreading and drooping habit; very attractive in flower and fruit. 2-3 feet, 25 cents; 3-4 feet, strong clumps, 50 cents.

* Lonicera involucrata, Bush Honeysuckle. Handsome foliage, berries enclosed in a purple involucre which is even more showy than the yellow flowers. Native from the Rocky Mountains to Alaska. 2-3 feet, 25 cents.

Lonicera Morrowi, Japanese Bush Honeysuckle. A shrub with wide spreading branches from four to six feet tall, leaves dark green, flowers white, changing to yellow, berries bright red. 2-3 feet, 25 cents.

Lonicera tatarica alba. A large shrub forming bushy clumps, flowers white, followed by a profusion of orange red berries which are exceedingly showy among the bright green leaves. 2-3 feet, 25 cents.

Lycium barbatum, Matrimony Vine. A trailing shrub, sometimes planted as a vine; one of the best things for covering dry banks or steep slopes, and on account of its dense matted growth will effectually prevent washing of soil. 3-5 feet, 25 cents.

* Opulaster glabratus, (Physocarpus), Nine Bark. A beautiful shrub resembling, and often included with the Spiraeas. Blooms very profusely in early spring, showy umbels of white or rose tinted flow- ers, 2-3 feet, 25 cents. Large clumps, 3-4 feet, 75 cents.

Opulaster opulifolia, Nine Bark. The largest growing of the Spiraea group, attaining 8-10 feet; a vigorous hardy shrub with white flower clusters and redish pods, handsome foliage. $3-4$ feet, 35 cents; 5-6 feet, 50 cents.

*Opulaster Ramaleyi, Ramaley's Nine Bark or Spiraea. Exceedingly vigorous with healthy Maple-like foliage, flowers larger, more showy, and the plant dwarfer and more compact than the eastern species; blooms so profusely that the branches bend with the weight of the flowers. 3-4 feet, 35 cents.

Philadelphus coronarius, Mock Orange. A graceful shrub of particularly refined appearance; sprays of snowy white four-partted frangrant flowers. 11/2-2 feet clumps, 25 cents.

Philadelphus grandiflorus, Large-flowered Mock Orange. A tall graceful shrub with arching branches, which bear a profusion of lovely pure white flowers. Sometimes called Syringa. 2-3 feet, 25 cents; 3-4 feet, 35 cents.

* Potentilla fruticosa, Shrubby Potentilla or Cinquefoil. A fine low-growing shrub which blooms all summer; flowers bright yellow. 1-2 feet, 25 cents.

*Prunus Besseyi, Dwarf Rocky Mountain Cherry. A dwarf shrub with spreading or reclining branches, handsome glossy foliage, fruit black or purple, variable in size and quality. A valuable shrub for landscape planting. 2-3 feet, 25 cents; $3-4$ feet, 35 cents.

Prunus Japonica, (Amygdalus) Flowering Almond. Flowers double, rose color $\mathrm{O}^{\circ}$ white, borne in great profusion in early spring; one of the most valuable flowerin's shrubs. 2-3 feet, white or rose, 50 cents.

*Prunus melanocarpa, Choke Cherry. Early blooming, flowers in drooping ra. cemes, fragrant; fruit black; a valuable ornamental. 2-3 feet, 25 cents.

Prunus triloba, Flowering Plum. Flowers double, pink or rose color, very profuse and showy, hardy and desirable. 3-4 feet, 50 cents.

Pte!ea trifoliata, Hop Tree or Wafer Ash. A handsome large shrub with very dark green foliage, especially attractive during the summer and fall with its clusters of broadly winged seeds which are creamy white and have the appearance of large flower clusters; 2-3 feet, 35 cents.

Rhamnus frangula. Alder Buckthorn. A large thickly branched shrub, quite symmetrical, attractive as a single specimen; berries like small cherries, red, turning to black. 4-5 feet, 35 cents,

Rhodotypus Kerrioides. White Kerria. A unique Japanese rosaceous shrub with neat foliage and large white syringa-like 
flowers, followed by black shining seeds which ornament the bush for weeks after the flowers are gone. 11/2-2 feet, 25 cents.

* Rhus glabra, Common Sumach. One of our most attractive shrubs at all seasons, the foliage is as graceful as a fern, and its autumn hues are the most brilliant of the native shrubs. It is so easily grown and so distinctly ornamental that it should be planted freely. $3-4$ feet, 25 cents; $\$ 15.00$ per hundred.

Rhus glabra laciniata, Cut-leaved Sumach. A dwarf variety with foliage as delicately cut as a fern, turning in the fall to vivid orange and scarlet. One of the

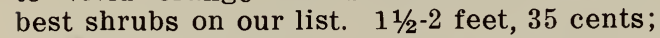
2-3 feet, 50 cents.

* Rhus glabra minor. Smaller and more slender than the common form, leaves smaller, darker green, very glossy above, silvery beneath. Fruit clusters small, bright red; a new sort and very desirable. 2-3 feet, 25 cents; $3-4$ feet, 35 cents; 4- 6 feet, 50 cents.

*Rhus trilobata, Three-leaved Sumach. A unique native shrub, of low, spreading

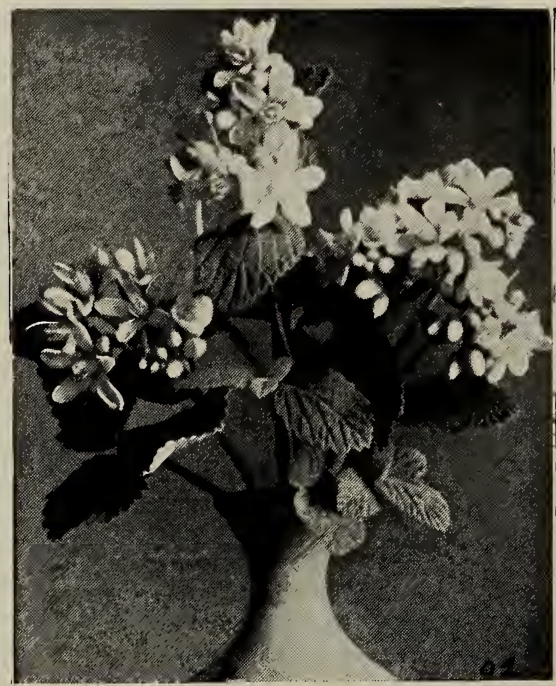

Jamesia Americana. Page 17.

foliage, the lower branches reclining upon the ground; the leaves are small, trifoliate; the fruit is bright scarlet, in clusters, ripening in June or July and remaining fresh till winter. It will grow and thrive on our most desert hillsides and always seems overflowing with vitality, and seems immune from insects or disease. $2-3$ feet, 35 cents; clumps 3-4 feet, 50 cents; 4-5 feet, 75 cents.

Rhus typhina, Stag-Horn Sumach. Resembles the common Sumach, but is much larger; a very picturesque shrub, the stout branches in winter having a fanciful resemblance to stag antlers. 2-3 feet, 25 cents; 3-4 feet, 35 cents; 6-8 feet, 75 cents.
Rhus typhina laciniata, Cut-leaved StagHorn Sumach. This has foliage as beautifully cut as Rhus glabra laciniata, but is a larger growing sort; not as large, however as the ordinary Stag-Horn. 2-3 feet, 35 cents.

*Ribes cereum, Red Musk-Currant. A low bush, red flowers and fruit. 2-3 feet, bushy, 25 cents.

*Ribes inerme, Thornless Gooseberry. A distinct species of robust upright habit with large foliage, scarcely thorny, ornamental and producing an abundance of purl le-black fruit. 2-3 feet, 25 cents; heavy clumps, 35 and 50 cents.

*Ribes longiflorum. (Ribes aureum) Golden Currant. A beautiful large growing shrub of gracefully spreading form, hand. some foliage and yellow clove-scented flow. ers and black or yellow fruit. 2-3 feet, 25 cents; 3-4 feet, 35 cents.

*Ribes saxosum, Common Wild Goose. berry. A very ornamental half-trailing shrub, suitable for banks or the edge of shrubberies and will grow in shade. 2-3 feet, 25 cents, $\$ 12.00$ per 100 .

\section{ROSA-WILD ROSES.}

The single flowered wild roses are exceedingly valuable for planting under semiwild conditions. Because of their ability so to thrive, immense quantities are used in parks and large estates. Most of the following sorts can be supplied in large quantities at special prices.

*Rosa Arkansana, Prairie Rose. This very dwarf rose seldom exceeds one foot in height, the flowel; are clustered, b'ooming in succession, and are very fragrant. The clusters of scarlet fruit are most conspicuous and remain bright all winter. 3 for 25 cents, $\$ 1.00$ per dozen $\$ 6.00$ per 100 .

*Rosa Engelmanni, Engelmann's Rose. 3-4 feet; a very stout bush, stems very spiny and leafy and forms denser clumps than most wild roses. As wild types are not uniform, I have selected and propagated from one which I consider most desirable. 25 cents.

*Rosa Fendleri, (Wcodsii of former lists.) Our tallest rose, 4-6 feet, not very spiny, quite leafy, the foliage turning to brilliant shades of red in autumn. Flowers and fruit in clusters, the latter very persistent. When planted in groups this rose forms splendid masses, and in winter the network of bright red twigs almost excels the Red-stemmed Dogwood. 25 cents.

Rosa lucida. One of the finest of the eastern wild roses, a native of New England and very hardy. The handsome foliage, low growing habit, profusion of bloom and persistent red fruit, together with its general air of refinement, combine in making it one of the best of all hardy shrubs. 3-4 feet, 25 cents.

Rosa lucida alba. This elegant variety 
has pure white flowers, without a tinge of color and the branches are green instead of the redish brown of the common form; it is the finest of single white roses. 2-3 feet, 50 cents.

Rosa multiflora. A trailing rose with clusters of small single white flowers followed by red berries. 3-5 feet, 35 cents.

Rose, Harrison's Yellow. This is the common yellow June rose, the first to b'oom, flowers half-double and deliciously fragrant. Its foliage and elegant habit of growth make it valuable for landscape planting; 2-3 feet, 25 cents.

Rose, Persian Yellow. Much like the last, but flowers deeper yellow and later; strong bushes, 35 and 50 cents.

Rosa rubiginosa, Sweet Brier.. Sweet scented foliage, single pink blossoms and scarlet, fruit persisting all winter make this a universal favorite. $2-3$ feet, 35 cents; small plants for hedges, $\$ 8.00$ per 100 .

Rosa rubiginosa hybrids, Lord Penzance Sweet Briers. These retain the fragrant foliage and have larger flowers in various colors. 50 cents and $\$ 1.00$.

Rosa rugosa. A stout vigorous rose with thick glossy foliage, blooms quite freely most of the summer, the large fruit soon ripening, so that both flowers and fruit mingle attractively with the dark foliage. 2-3 feet, 35 cents.

Rosa rugosa alba. A little dwarfer than the type, and the orange-scarlet fruits are even larger, often as large as small crabapples. There is no danger of praising this shrub too highly. 35 cents.

*Rosa Sayi. A mountain species which is quite dwarf but taller than Arkansana; foliage cinnamon scented. 25 cents.

* Rubus deliciosus, Thimble Berry or Flowering Raspberry. One of our choicest natives, with strong branching, thornless canes, forming bushy clumps which in spring are weighted down with a profusion of fragrant snow white flowers as large as single roses, which they much resemble; very hardy and easily grown. Very fine stock, 2-3 feet, 35 cents.

*Salix irrorata, Blue Willow. Large shrub, not spreading, branches in winter coated with a blue-glaucus bloom. 5-6 feet, 35 cents.

Salix rigida. A trailing willow with bright yellow bark and narrow lance-like foliage; fine for banks; large clumps 35 cents.

Sambucus Canadensis, American or Sweet Elder. A large shrub of magnificent proportions, leaves compound, flowers white, in very large flat topped cymes, fruit black. 3-4 feet, 35 cents.

Sambucus nigra laciniata, Cut-leaved Elder. A large shrub, sometimes 10-12 feet, of bushy habit, blooming freely, and one of the finest shrubs for foliage on our list. The leaves are a dark glossy green, and cut into fern-like segments; entirely hardy. 2-3 feet, 25 cents.

*Shepherdia argentea, Buffalo Berry. A large shrub of vigorous, thrifty habit, beautiful silvery white foliage, resembling Russian Olive to which it is related; berries very abundant, bright scarlet, acid but of desirable quality, ornamental, remaining on the bush many weeks in good condition. Of utmost hardiness and adaptability, growing naturally both on dry exposed bluffs, and in low. wet alkaline soil. Of unique importance for landscape planting. Should be planted in groups to secure fruit as it is bisexual. 2-3 feet, 25 cents.

EARLY FLOWERING SPIRAEAS.

Spiraea arguta, Snow-Garland Spiraea. Remarkably floriferous and showy; somewhat larger growing than Thunbergii which it resembles. One of our finest early-flowering shrubs and one of the first to bloom. 3-3 feet, 25 cents; $3-4$ feet, 35 cents.

Spiraea prunifolia, Bridal Wreath. Double white flowers in long wreath-like sprays; a graceful shrub with shining foliage which turns to purplish red in autumn. 3-3 feet, clumps, 35 cents.

Spiraea Thunbergii, Thunberg's Spiraea. A small graceful shrub with numerous slender branches and minute foliage, giving a light airy effect; leaves light green, flowers small, double, pure white, in greatest profusion. 2-3 feet, 35 cents.

Spiraea Van Houttei, Van Houtte's Brid. al Wreath: The pendulous branches sweep. ing to the ground with their load of snowwhite flowers, makes the name. "Bridal Wreath," very appropriate; a grand and graceful shrub, exceptionally neat and attractive at all seasons. $3-4$ feet, 25 cents; 4-5 feet, clumps, 50 and 75 cents.

SUMMER-FLOWERING SPIRAEAS.

Spiraea, Anthony Waterer, Crimson Spiraea. A dwarf bushy sort about two feet tall with rosy crimson flowers in dense clusters all summer and until frost. 1-11/2 feet,

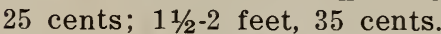

Spiraea callosa rosea, Pink Spiraea. With urright stems 3-4 feet tall; flowers rose rink, in large flat-topped panicles. $1 \frac{11 / 2-2}{2}$ feet, 25 cents.

Spiraea Billardi, Billiard's Spiraea. Flowers bright pink, produced in long dense panicles through the summer. 2-3 feet, 25 cents.

Spiraea Douglasii rosea, Douglas Spiraea. A late summer-blooming bush with leaves silvery white underneath, flowers deep rose in long dense upright clusters. 2-3 feet, clumps, 25 cents.

Spiraea Lindleyana, Elder-leaved Spiraea. A semi-herbaceous species dies down during the winter, but produces a luxuriant new growth, furnished with handsome foliage, each stem terminating in a large white 
flower-plume. Strong plants, 25 cents.

Spiraea salicifolia alba, Willow-leaved Spiraea. An upright shrub, growing 5-7 feet tall, flowers white, in large pyramidal panic'es, blooming most of the summer. 2-3 feet, 25 cents; 5-6 feet, clumrs, 75 cents.

*Symphoricarpos occidentalis, Wolf Berry. A large-leaved sort with yellowish white berries; excellent for dry places or poor soils where few other shrubs will thrive. 15 cents; $\$ 8.00$ per hundred.

* Symphoricarpos occidentalis macro. phylla. A variety with very large foliage and more vigorous habit; will grow in dry places and under trees. 2-3 feet, 25 cents.

*Symphoricarpos pauciflorus, Small Snow Berry. A select form, fruiting more freely than the ordinary. 1-2 feet, 15 cents; $\$ 8.00$ per hundred.

Symphoricarpos racemosus. Large Snow Berry, the large white berries white as wax and remaining so all summer make this a most delightful acquisition, and should bo associated with the red berried species in every shrub collection. 2-3 feet, 25 cents.

Symphoricarpos vulgaris, Indian Cur. rant. This is not only one of the best foliage shrubs for massing, but it bears a pro. fusion of bright red berries which in this climate remain fresh nearly all winter; succeeds anywhere. 2-3 feet, 25 cents; heavy clumps 50 cents.

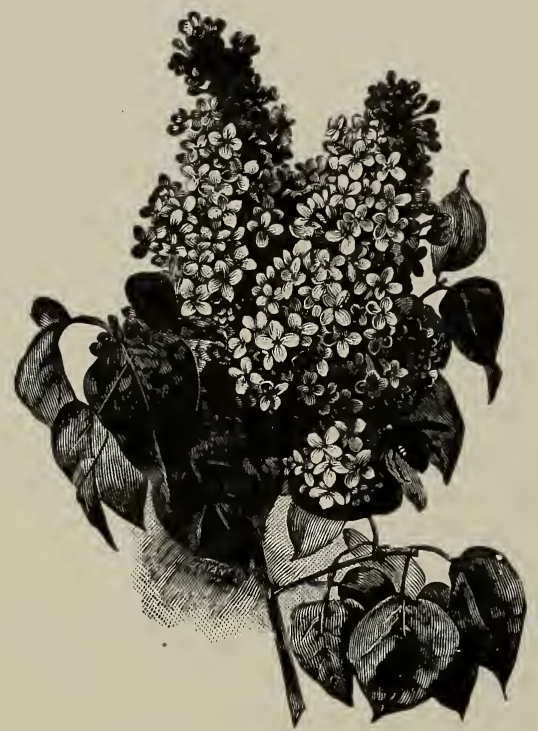

Syringa, Garden Lilac.

Syringa Josikea, Hungarian Lilac.. A sturdy vigorous shrub with upright branches; leaves large, dark green and shining: flowers violet, in long narrow panicles and a very sure bloomer because the blooming season is nearly a month later than other sorts and are consequently uninjured by frost. Clumps, 3-4 feet, 75 cents.
Syringa Pekinensis, Chinese Lilac. This is a summer blooming sort with panicles of white flowers and may be pruned to a single trunk making a small tree. 6-8 feet, 50 cents.

Syringa Persica, Persian Lilac.. A graceful shrub with slender branches, bushy habit, blooms a little later than the common Lilac, 2-3 feet, 35 cents.

Syringa Rothomagensis, Red Persian or Rouen Lilac. A choice variety very similar to the Persian but of more vigorous habit; thrifty and free blooming. 2-3 feet, 25 cents 3-4 feet, bushy clumps, 50 cents.

Syringa vulgaris, Common Lilac. A well known and long cherished shrub with attractive foliage, always healthy and free from insects, flowers deliciously fragrant. 3-4 feet, clumps, 35, 50, and 75 cents.

Syringa vulgaris alba, pure white variety, 2-3 feet, 25 cents; 3-4 feet, 35 cents.

\section{HYBRID GARDEN LILACS.}

During recent years various French growers have attained marvelous success in improving the Lilac. Many of the new varieties have double flowers of rare beauty and excellence. The individual flowers of the double sorts are perfectly formed, tne panicles of largest size and bushes bloom as freely and are as hardy as the singles. The new single varieties have very large and perfect individual flowers, of improved clear colors, and immense panicles. All have the delicious perfume of the common Lilac. Lilacs improve with age, endure neglect, but respond freely to good care and favorable conditions. This is especially true of the improved forms. The following var. ieties are supplied in strong bushes, 2-3 feet, 50 cents each.

ÁLPHONSE LAVALLE, double, blue shaded violet.

CHARLES X., single, large loose truss redish purple. let.

CHARLES SARGENT, single, dark vio-

EMILE LEMOINE, double, very large, perfect form, rosy lilac.

FRAU BERTHA DAMMANN, single, pure white, very fine.

JEAN, BART, double, large compact panicle, rosy carmine.

LA TOUR D' AUVERGNE, double, very large, violet purple.

LUDWIG SPATH, single, individual flowers and panicle large, very deep purple; superb.

MADAME LEMOINE, double, exquisite flower, pure white.

MICHAEL BUCHNER, very double, large panicle, pale lilac.

RUBRA DE 'MARLY, single, rosy lilac.

Viburnum cassinoides, Withe-rod. A handsome hardy shrub, growing north to Manitoba. Flowers creamy white in flattopped clusters, followed by pink berries 
which turn to blue. Clumps, 2-3 feet, 50 cents.

Viburnum, Lantana, Wayfaring Tree. A large shrub, leaves wrinkled, dark green above, downy beneath, with coarsely toothed margins; flowers pure white, in flattopped clusters. 2-3 feet, 25 cents; 3-4 feet, 35 cents.

*Viburnum Lentago, Black Haw. Low bushy tree, remarkably symmetrical in form, glossy dark green foliage, turning red and orange in autumn. This is a native, or at least has become naturalized near Bou?der, and is therefore especially well suited to this climate. Extra fine clumps, 2-3 feet, 35 cents; $5-6$ feet, clumps $\$ 1.00$.

Viburnum molle, Arrow-wood. Named from the straight upright shoots, the foliage dark green with dentate margin, flowers white, berries blue-black. Forms handsome symmetrical clumps. $2-3$ feet, 35 cents; $3-4$ feet, 50 cents.

Vikurnum opulus, High Bush Cranberry. A handsome shrub 8-10 feet tall, with spreading bushy habit; flowers in large flat clusters, followed by showy red fruit. 2-3 feet, 25 cents; $3-4$ feet, 35 and 50 cents.

Viburnum opulus sterillis, Common Snowball. A grand old-fashioned shrub with showy flowers in large globular clusters; one of the best of flowering shrubs. 2-3 feet, 25 and 35 cents; heavy clumps, 4-5 feet, $\$ 1.00$.

Xanthoceras sorbifolia. Chinese Fiowering Buckeye. A large shrub bearing a profusion of beautiful flowers which are white with a yellow blotch, in long racemes at the ends of the branches. Hardy both at Fort Collins and Greeley; thrives in a well drained loamy soil; foliage pinnate, resembling the Mountain Ash. 1-2 feet, stocky plants, 50 cents.

\section{HARDY HERBACEOUS PERENNIALS}

Hardy plants are rapidly gaining in popularity, taking the place of tender bedding plants. Besides reducing the cost of annual renewal and maintenance, they greatly prolong the season, bursting into growth with the advent of spring, and throughout the growing season afford a wealth of flowers and foliage until long after the tender plants have been cut down and their brief season ended.

Among hardy plants, I like those which thrive easily with no special care other than good cultivation and watering when needed; such as, peonies, phlox, iris, columbine, hibiscus, Shasta daisies, brown-eyed susans, and hollyhocks. There are others as good but not so well known, like the perennial asters, heleniums, liatris, and blue salvias which bloom in the fall when good flowers are scarce; the hardy ferns and grasses for their decorative foliage; the bleeding heart, delphinium, lily-of-the-valley, day lilies and tiger lilies among old fashioned flowers which are apt to be overlooked; and the herbaceous clematis and spiraeas, the veronicas, lespedeza, coreorsis, platycodon, sedum and tritoma which are among the newer things that should be grown in every garden.

If you give these hardy flowers only one half the care that you must give tender plants or the vegetable garden you will be repaid a thousand fold for your effort; however, lack of care should not approach neglect. In laying out anything as permanent as a bed or border of hardy plants the most thorough preparation is the only sure road to success; and such preparation is profitable, because it lightens subsequent care. Deep spading, with the addition of loam and sand to clay soils, together with a moderate application of finely pulverized fertilizer, is a safe rule with no important exceptions. If the soil is prepared in autumn for spring planting, which is probably the best planting season for everything except peonies, lilies and spring-flowering bulbs, the freezing during the winter will do a great deal toward improving the soil. I would not fail to state that early fall planting in October, not later, is safe for the majority of hardy flowers. No fixed rule can be given for the depth to plant. Often the clump will show the depth on stem or leaves. As a general rule the crown where the new growth begins, should be one inch to four inches below the surface, according to the size and vigor of the plant. Peonies should be planted about four inches deep, phlox about two inches, German iris should have the large rhizomes barely covered and the Japanese iris somewhat deeper. The principles of planting as explained in my "LITTLE RED BOOK" on Planting and Care of Trees will apply in general equa!ly well to hardy flowers. 


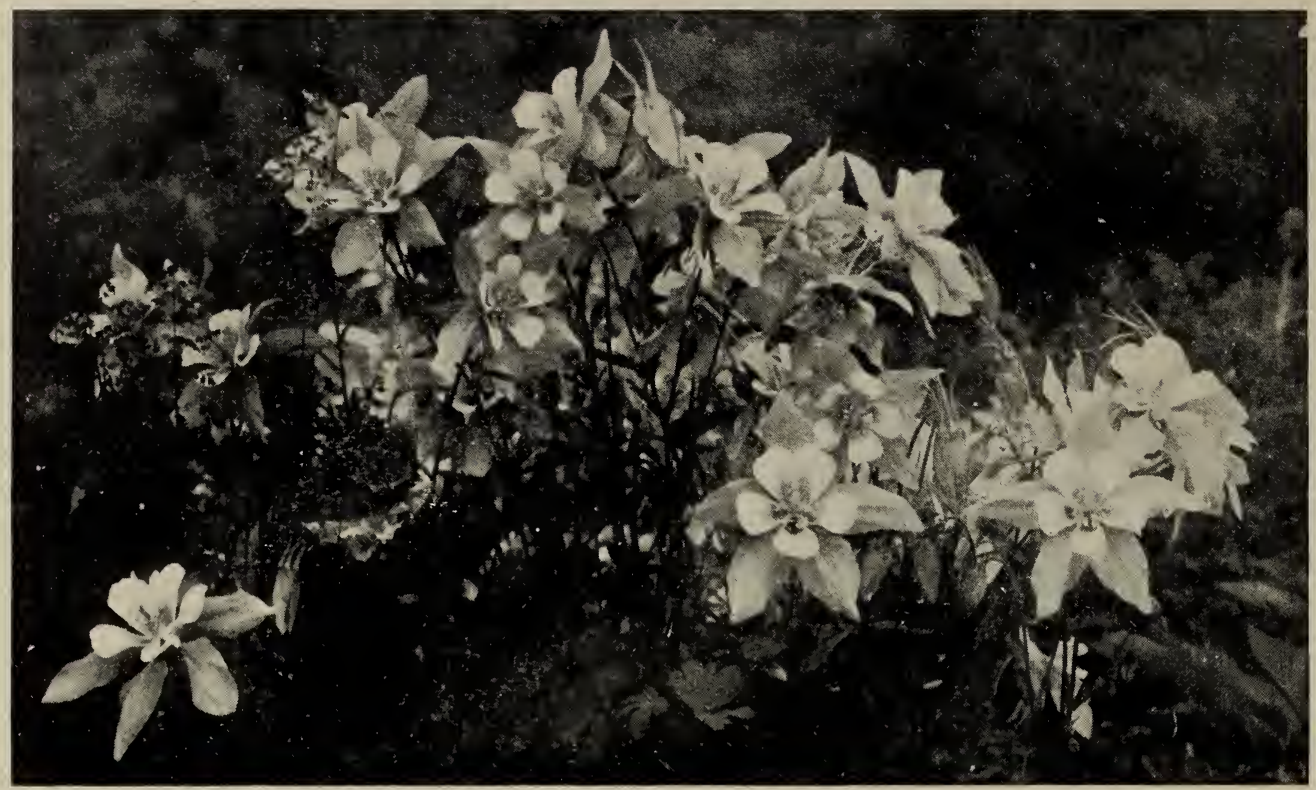

Rocky Mountain Columbine, Aquilegia.

\section{ACONITUM (Monkshood).}

Aconitum Fischeri, 2 feet; spike of flowers clear corce'ain-blue, large and showy; September.

\section{AQUILEGIA (Columbine).}

Aquilegia coerulea, Rocky Mountain Columbine, the State Flower; 2 feet; unique among columbines, the sepals are lavender, the petals pure white, the flower often four to five inches across; with long slender spurs. Strong plants in two grades, $\$ 1.00$ and $\$ 1.50$ per dozen.

Aquilegia chrysantha, 3 feet; a most profuse bloomer nearly all summer, flowers golden yellow.

ASCLEPIAS (Butterfly-weed).

Asclepias tuberosa, $1 \frac{1 / 2}{2}$ feet; makes a brilliant display neariy all summer with showy umbels of orange or vermilion-red flowers.

Asclepias incarnata, 4 feet; slender clumps, flowers rose.

\section{HARDY ASTERS.}

The perennial asters or Michaelmas Daisies are becoming more and more popular because of the wealth of blossoms produced in late autumn when flowers are scarce; the latest ones stand severe freezing without harm. Price of Hardy Asters, 15 cents, $\$ 1.50$ per dozen.

Aster NovarAnglae, 4 feet; individual florets an inch broad, and literally covering the plant; rich violet purple.

Aster Nova-Anglae, (tall late variety) 5 feet; very late, true royal purple.
Aster Nova-Anglae rosea, 4 feet; differs only in color which is a fine clear rose.

Aster, Wm. Bowman, 3 feet; lavenderblue.

Aster, White Queen, 3 feet; fine pure white. Price of asters, $\$ 1.50$ per dozen.

BOCCONIA (Plume Poppy).

Bocconia cordata, 4 feet; a stately plan: with beautiful glaucus foliage and creamy. white flower plumes; 15 cents, $\$ 1.50 \mathrm{per}^{\circ}$ dozen.

\section{CASSIA (American Senna).}

Cassia Marilandica, 3 feet; strong erect stems with finely pinnate foliage, large panicles and axillary clusters of yellow, curiously shaped flowers; a very desirable plant; 15 cents, $\$ 1.50$ per dozen.

\section{CENTAUREA (Cornflower).}

Centaurea purpurea, $21 / 2$ feet; a most elegant plant, not spiny, but with rose purple thistle-shaped heads of flowers; obtained from the Royal Gardens of Belgrade, Servia; 25 cents.

\section{HERBACEOUS CLEMATIS.}

Many who are familiar with the climbing sorts are surprised to learn that there are bushy kinds which never climb. All are hardy and have handsome foliage and showy flowers, and are easily grown.

Clematis Davidiana, (see cut) 2 feet; a stout bush with magnificent foliage and clusters of deep lavender-blue flowers; 20 cents, $\$ 2.00$ per dozen.

Clematis integrifolia, 2 feet; flowers about half the size of the well known Jack- 


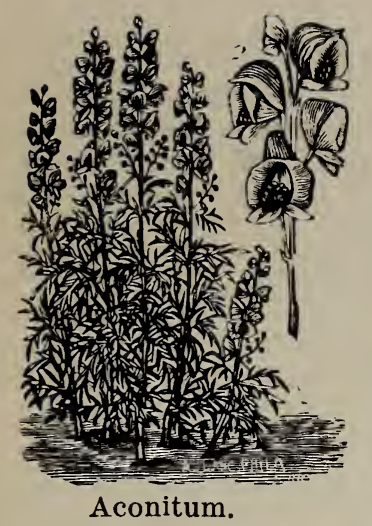

manni, and of the same shape and color, produced most of the summer and are followed by beautiful seed-plumes; 20 cents, $\$ 2.00$ per dozen.

Clematis recta, $2 \frac{1}{2}$ feet; a handsome bush with flowers and foliage resembling Clematis paniculata; flowers pure white in large clusters; 20 cents, $\$ 2.00$ per dozen.

CONVALLARIA (Lily of-the-Valley).

Convallaria majalis Grandiflora. Large flowered Lily-of-the-Valley. This is so much superior to the ordinary sort for out door planting that we urge everyone to try it. It may not show much superiority the first season but when established the pure white bells are fully twice the size of the ordinary variety and exquisitely fragrant. It also has longer stems and larger foliage.

\section{COREOPSIS.}

Coreopsis grandiflora, 2 feet; good shades of yellow that are desirable for cut flowers, and which make a grand display in the garden, are scarce; in this we have perfection in both; flowers as large as Cos. mos, on long stems and blooms nearly all summer.

\section{DELPHINIUM (Larkspur).}

Delphinium formosum, 3 feet; flowers deep indigo with white center, larger than a silver dollar, arranged in long spikes and are excellent for cutting. 15 cents, $\$ 1.50$ per dozen.

\section{DICTAMNUS (Gas Plant).}

Dictamnus fraxinella, 2 feet; fragrant foliage and spikes of odd-shaped flowers in June and July; one of the most enduring of all perennials and improves with age; two colors, pure white and rose-pink; either kind, 15 cents, $\$ 1.50$ per dozen.

\section{DICENTRA (Bleeding Heart).}

Dictentra spectabilis, 2 feet; this oldfashioned favorite should have a place in every garden; its long drooping racemes of heart shaped pink blossoms are very attractive; will grow in shade; 15 and 25 cents.

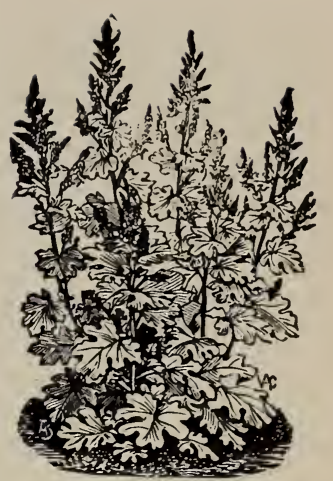

Bocconia.
GERANIUM (Crane's Bill).

Geranium pratense album. Hardy White Geranium or Cranesbill. Flowers pure white all summer.

Geranium sanguineum, Hardy Red Geranium. A good plant for edging beds of shrubbery or other hardy plants; produces a dwarf dense spreading growth of beautiful foliage which assumes beautiful autumn colors, covered all summer with deep red flowers. $\$ 6.00$ per 100 .

\section{GILLENIA (Bowman Root).}

Gillenia trifoliata, 2 feet, resembling the Herbaceous Spiraeas, a strong growing plant with handsome foliage and sprays of white flowers tinted rose; large clumps, 25 cents.

\section{HELENIUM (Orange Daisy).}

A recently prominent group of late autumn bloomers, of easiest culture, and grandly decorative, either in the garden or as a cut flower. The later ones stand severe freezing. Price of all varieties, 10 cents each, $\$ 1.00$ per dozen.

Helenium autumnale superbum, 4-6 feet; pure golden yellow.

Helenium autumnale rubrum, like the last, but flowers bright terra-cotta red; very effective.

Helenium, Riverton Gem, 3 feet; this, like the others, has flowers the size and form of the hardy asters; flowers deep bronze, striped and suffused with bright terre-cotta red.

\section{HARDY GRASSES.}

Few people realize the really wonderful effects that can be produced with tne Hardy Ornamental Grasses. For a co'd climate the effect is more nearly tropical than anything else we can have. They are rank feeders and require a rich soil with plenty of moisture. The most effective arrangement is a large bed with the taller kinds at the center, or in a border with the tall kinds at the back; the smaller kinds and Yucca near the edge. The following kinds are hardy:

Price of Hardy Perennials, except where noted, 10 cents each, $\$ 1.00$ per dozen. 
Elymus glaucus, Blue Lyme Grass. Suitable for the border or front of beds containing larger sorts; about two feet tall, foliage silvery glaucus, very handsome. 25 cents. $\$ 2.50$ per dozen.

Erianthus Ravennae, Hardy Pampas. Forming clumps 8-10 feet, with snowy Pampas-like plumes on every stem. 25 cents $\$ 2.50$ per dozen.

Eulalia gracillima, Japan Rush. 4-5 feet, forming clumps with slender recurving foliage; one of the finest. Clumps, 25 to 50 cents, $\$ 2.00$ per dozen.

Eulalia Japonica variegata. A very ornamental variety with narrow leaves striped green and white. 25 cents, $\$ 2.00$ per dozen.

Eulalia Japonica zebrina, Zebra Grass. A large sort ,foliage beautifully cross barred with yellow; very striking; handsome plumes in autumn; clumps 25 to 50 cents, $\$ 2.00$ per dozen.

Festuca glauca, Blue Fescue.. A dwarf tufted grass with glaucus blue foliage; very beautiful for low edgings. Clumrs 15 cents; $\$ 1.50$ per dozen.

\section{GYPSOPHILA (Baby's Breath).}

Gypsophila paniculata, 3 feet; indispensable both for garden decoration and for cutting; large sprays bearing myriads of minute white flowers. 15 cents, $\$ 1.50$ per dozen.

\section{HEMEROCALLIS (Yellow Day Lily).}

Popular hardy Lilaceous plants with tuberous roots, and which succeed everywhere. The flowers resemb!e lilies, and are 3 to 6 inches broad, borne on many slender stems well above the foliage.

Hemerocallis flava, Lemon Lily. Flowers pure lemon-yellow, very fragrant, in great profusion during June and July; 3 feet high.

Hemerocallis Florham. A new hybrid variety with deep golden yellow flowers of largest size and a persistent b'oomer. This and the Lemon Lily cannot be too highly commended. 15 cents, $\$ 1.50$ per dozen.

Hemerocallis Kwanso plena. The largest of all, growing 5 to 6 feet tall; large perfectly double flowers, deep orange shaded darker toward the center.

Hemerocallis Middendorfii. Very dwarf flowers deep golden yellow.

Hemerocallis Thunbergii, Lemon Yel. low, late.

\section{HIBISCUS (Rose Mallow).}

Tall free flowering perfectly hardy plants with remarkably large and showy flowers. The individual flowers resemb?e a single Hollyhock, but are much larger. All varieties including the Mallow Marvels require plenty of water during the growing and blooming season.
Hibiscus militaris, Halbert-leaved Rose Mallow. This differs from the common Rose Mallow in both flowers and foliage, but has the same bold habit of growth giving it the appearance of a shrub, but like the other sorts it dies down to the ground each winter and produces its magnificent blooms on the new growth. 15 cents, $\$ 1.50$ per dozen.

Hibiscus moscheutos, Rose Mallow. Stout, 3-4 12et, forming bushy shrub-like clumrs, bearing a long succession of magnificent blooms, light rose with a purple eye. Strong roots that will bloom this season, 15 cents, $\$ 1.50$ per dozen.

Hibiscus oculiroseus, Crimson Elye. Nearly identical with the last, but the flowers are pure white with large crimson eye. 15 cents, $\$ 1.50$ per dozen.

Hibiscus, Meehan Mallow Marvels. The most remarkable hardy flower creation of many years. They are hybrids of the Rose Mallow with a red flowered southern species which with subsequent breeding and selection has given us a plant of unquestioned hardiness, has lengthened the blooming season, has improved both the vigor and growing habit of the plant, as well as the character of the foliage. The flowers also are larger and the petals more spreading, while their delicate silky texture takes away any suggestion of coarseness. The range of color is superb, the tones clear and very pleasing. They show almost every tint from white to crimson. We offer strong roots which will bloom freely this season, in four colors, white, pink, red and crimson at 35 cents, $\$ 3.50$ per dozen.

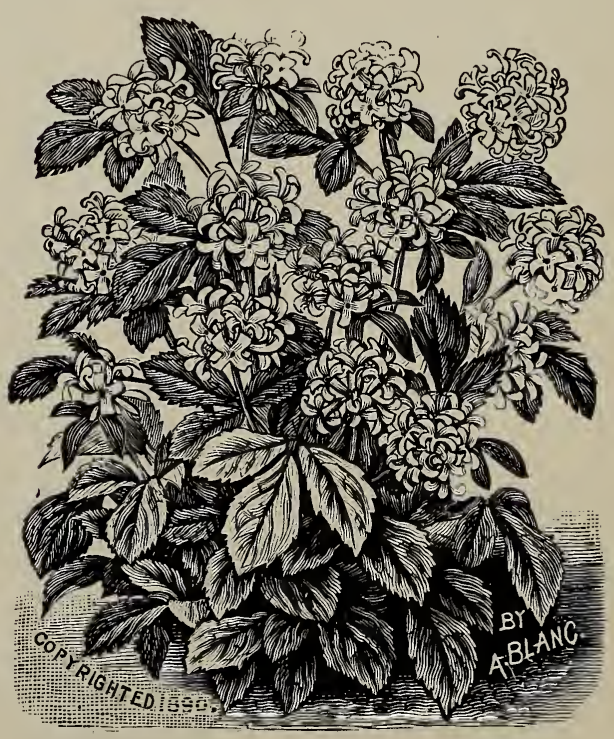

Clematis Davidiana.

Price of Hardy Perennials, except where noted, 10 cents each, $\$ 1.00$ per ciozen. 


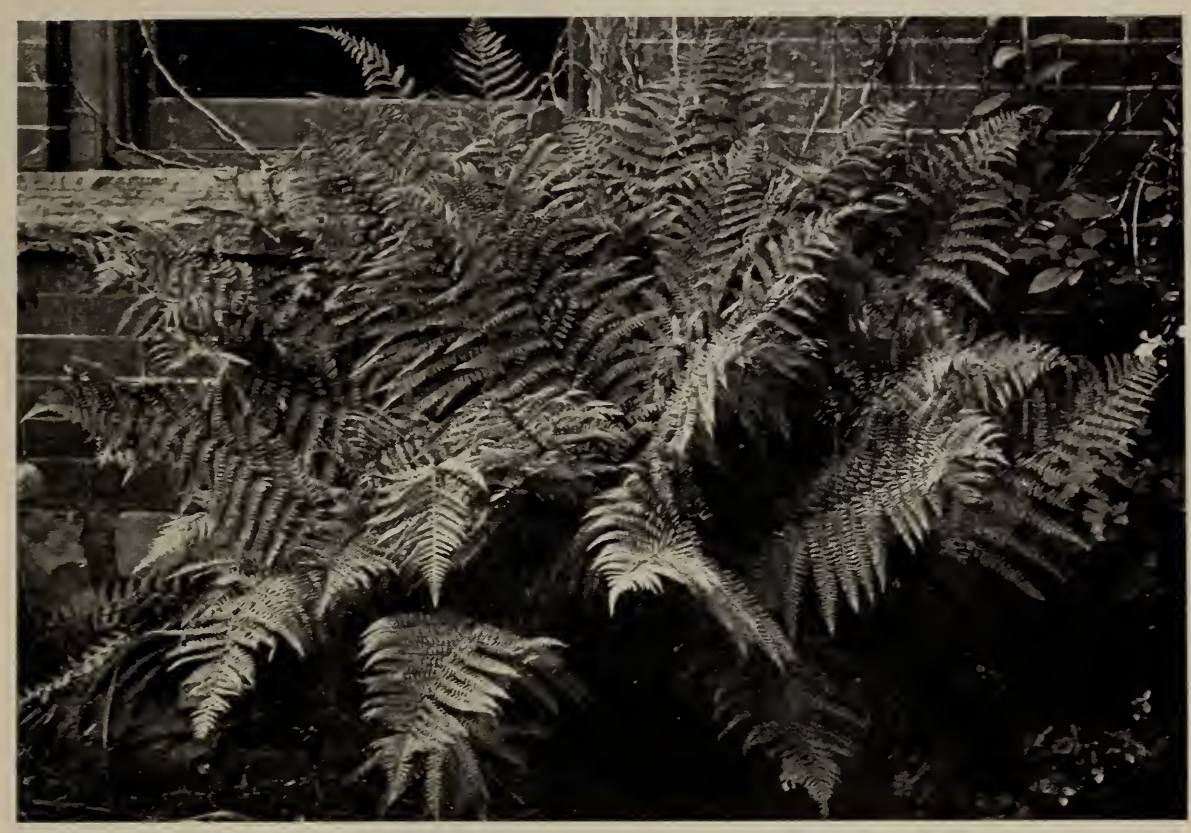

Aspidium Felix-mas, the Colorado Male-Fern.

\section{HARDY FERNS}

For planting in densely shaded places where flowering plants wiil not thrive, there is nothing more satisfactori.y than Hardy Ferns. For decorative effect there is nothing else among hardy plants that surpasses them. The essential requirements for success with ferns are shade, plenty of moisture, and a soil rich in back humus or leaf mold. If these things are not lacking, a most delightful effect can be produced by planting a fern border along a north wall. Our illustration shows a clump of Aspidium Felix-mas growing on the north side of our office.

The soil, if correctly prepared, makes success with ferns just as certain as with any other hardy plants. If the natural soil is a mellow loam, the addition of leaf mold at the rate of one sack to the square yard of bed will insure excellent results. Part of this should be worked int. the soil before planting, and the remain. der applied over the surface as a mulch. Ferns do not require a deep soil but it must be of suitable quality. In planting do not entirely cover the large bud, from which will unfold the new growth. The plants should be set moderately close together, about 12 to 20 to the square yard of surface; they thrive much better if the ground is en. tirely covered with a growth of the fronds. We offer leaf mold for fern beds at $\$ 1.00$ per sack, six sacks for $\$ 5.00$. The fo'lowing kinds are recommended for this climate. price for any kind or assorted, 15 rents each, $\$ 1.50$ per dozen, $\$ 12.00$ per 100 .

Aspidium achrosticoides. One foot tall evergreen, known as the Christmas Fern; one of the best to plant in front of the larg. er kinds.

*Aspidium Felix-mas. Two feet, forms large clumps of dark green foliage; one of the very best. See illustration above.

Aspidium marginale. $1 \frac{1}{2}$ feet, easily grown, very handsome, remains green nearly all winter.
Onoclea sensibilis, Sensitive Fern or Oak-leaf Fern. A foot tall, very handsome foliage.

Onoclea strutiniopteris. Ostrich Fern. One of the grandest of hardy ferns; the fronds grow about three feet tall and stand in a vase-like position; easily grown.

*Woodsia scopulina. A small native which may be used in dry places. 


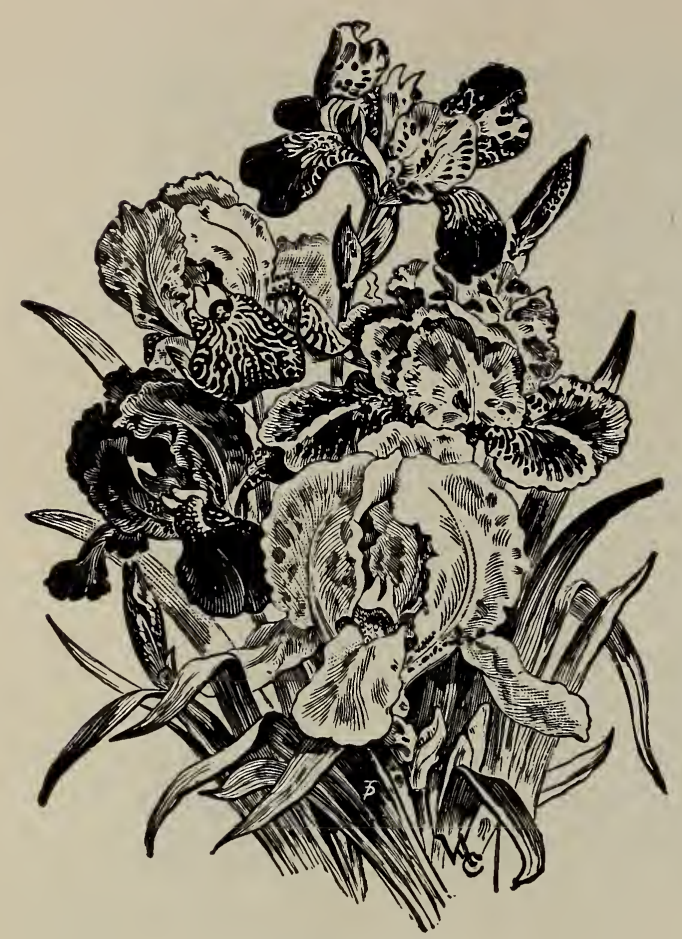

German Iris.

ROCKMONT HOLLYHOCKS.

The finest strain of double Hollyhocks that can be produced by careful breeding and selection. As a background for large borders and for planting along fences and among shrubbery there is nothing finer. Four separate colors, yellow, white, pink, red, either color or assorted, 15 cents, $\$ 1.00$ per dozen, $\$ 8.00$ per 100 .

GERMAN IRIS-Fleur de-Lis.

There is a peculiar charm about the Iris which puts it in a class distinct from all other flowers. It is found in the ethereal texture of the peta's, its classic outlines which have always inspired the artist, and in its soft and irridescent co'oring, suggesting the rainbow from which it derives its name.

The modern flower is a revelation, no Orchid is more beautiful, yet their requirements remain as simple and unexacting as the old-fashioned "Flag." The German Iris likes a dry, sunny situation, and in this the climate of Colorado affords an ideal environment. They require only a little more moisture than our natural rainfall and this during the blooming season. In the mountains at quite high altitudes they are particularly successful, the natural moisture being sufficient. Prices are for strong natural divisions; for clumps set three or more together. 10 cents each, $\$ 1.00$ rer dozen, except where noted.
Celeste, pale azure blue; tall.

Flavescens (Canary Bird), a delicate creamy-yellow, large and fragrant; $\$ 6.00$ per 100.

Florentina alba, white, with a faint tinge of lavender-blue; fragrant and early; $\$ 6.00$ per 100 .

Gracchus, standards (upright petals) yellow, falls (deflexed petals) crimson, reticulated white, extra fine; $\$ 6.00$ rer 100 .

Her Majesty, standards a lovely rose rink, falls shaded much deeper; 25 cents.

Madam Chereau, white, elegantly frilled with a border of clear blue; tall and late; $\$ 6.00$ per 100 .

Mandraliscoe, large lavender-purple flow. er, 25 cents.

Mrs. H. Darwin, pure white, falls reticulated violet; 25 cents.

Mrs. Neubronner, the largest and finest pure yellow iris, deep golaen yellow and a free bloomer; 25 cents.

Pallida Dalmatica, deep lavender, tinged violet; very large flower; 25 cents.

Plumeri, deep copper-red with smoky tinge, very effective.

Rigolette, standards yellow, falls mahog: any-brown, very rich; $\$ 6.00$ per 100 .

Spectabilis, early and dwarf; very rich deep purple; $\$ 6.00$ per 100 .

Tinaea, handsome glaucus foliage, flowers lilac; $\$ 6.00$ fer 100 .

Victorine, standards white mottled blue, falls violet blue; 25 cents.

\section{VARIOUS IRIS.}

Iris pumila hybrida, form of flower and style of growth same as the German iris, but very dwarf and two or three weeks earlier. Culture exactly the same, and very satisfactory for edgings. Three varieties, Eburnea, white, $\$ 1.50$ per dozen; Florida, yellow with deeper shading, $\$ 1.50$ per doz. en; Cyanea, very dwarf dark purple, $\$ 1.00$ per dozen, $\$ 5.00$ per 100 .

Iris versicolor, 3 feet; a very rank growing sort for ditch banks and water-side planting; flowers blue; $\$ 5.00$ per 100 .

Iris pseudacorus, Giant Yellow Iris, 3-4 feet; a magnificent flag for water-side planting with long arching foliage and bright yellow flowers and grows equally well in the garden; clumps, 15 cents, 25 cents and 50 cents.

Iris Missouriensis, the native iris of the mountains and in wild meadows; beautiful in cultivation, flowers about the same shade as the mountain columbine and nearly as showy. $\$ 5.00$ per 100 .

JAPANESE IRIS (Iris laevigata).

The Japanese Iris are the last to bloom, coming after the German varieties are gone. They close the season with a glorious and most satisfactory climax. Their culture rresents no difficulties but they will not stand neglect like the German Iris. They require plenty of moisture during the grow. 
ing season and a mellow soil containing fertility suflicient to produce a strong vigorous growth which is necessary for the full development of their enormous blooms measuring seven to nine inches across. One secret of success with Japanese Iris is to keep the ground mellow and well stirred. never a'lowing it to bake or become hard on the surface. Stiff clay should be avoided, or well mixed with sand or loam.

My collection was imported from Japan the winter of 1900-1, and at first numbered 35 varieties, picked from a larger assort. ment. From these I have reselected the most distinct, the best bloomers and those combining the best color effects. For the result, which is the list offered below, I claim the following points of superiority: first, the cream of more than 100 varieties; second, ten years of study and selection in the climate where they are offered for planting; third, plants thoroughly acclimated; fourth, every plant true to name and description, having bloomed all the plants many times over.

Frice, except where noted, 25 cents, $\$ 2.50$ rer dozen. A dozen will include an assortment of the 25 cent varieties; order by number for serarate kinds. I have several other named sorts which I offer to close out, at $\$ 1.50$ rer dozen, assorted.

Double, six-petaled Japanese Iris.

12. Kuma-funjin, finely dotted and marbled blue and purple.

17. Shippo, lilac blue, white center with radiating white veins, slightly ruffled petals.

20. Kumo-no-uyi, deep purple, shaded indigo; very full, center slightly crested.

21. Yezo-nishiki, grayish blue, stained ultamarine blue, finely freckled white.

22. Shishi-ikari, white center, radiating and diffusing into a border of wine-red.

30. Kagaribi, purplish red with paler veining.

31. Kosui-no-iro, white, with strong violet veinings; extra good.

32. Komochi-guma, clear deep purple, three large crested stigmas; 35 cents.

33. Kaku-juku-ro, lavender, marbled and dotted purple, mauve stigmas; 35 cents.

35. Shuchiu-kwa, purple lilac, white center, $10-12$ petals.

100 Ayaregawa, blue, veined indigo, conspicuous indigo crest; 35 cents.

105. Kinnoko, white with violet stigmas, delicately veined.

109. Taihai, pure white, a grand flower; 35 cents.

112. Yasenga-kara, white, with distinct halo of violet-rose, with deeper veins extending to the center and margin; 35 cents.

119. Ginhoi, grayish, finely freckled purple, some flowers overlaid with nearly clear purple.

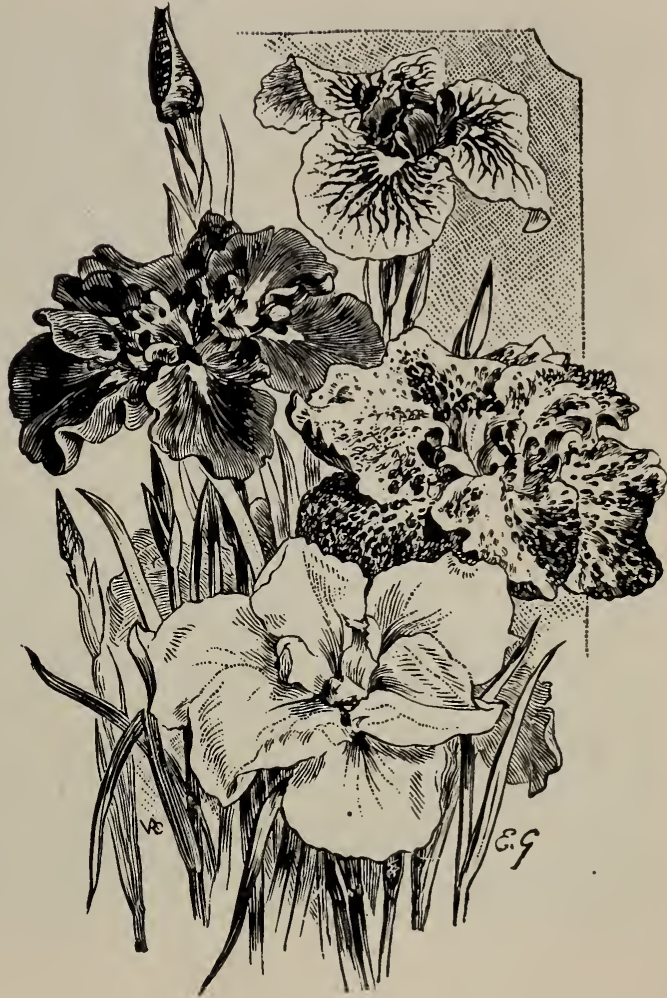

Japanese Iris.

Single, three-petaled Japanese Iris.

19. Kimi no-megumi, pale lavender, veined deep purple.

34. Momiji-no-tuki, grayish blue, veined violet blue, stigmas violet.

67. Kigan-no-misao, a late pure white; 35 cents.

104. Nishiki-moshitone, mauve, center shaded blue.

\section{LESPEDEZA (Desmodium).}

Lespedeza Sieboldi, (Desmodium penduliflorum) Drooping Bush Clover. A native of Japan, and like most of the Clover family is perfectly at home in this climate. In early autumn the numerous wiry stems which grow three or four feet tall become loaded and droop to the ground with the myriads of brilliant rose purple flowers which resemble small pea blossoms. Although not well known, its striking yet graceful appearance makes it dear to all who see it in b.oom. Strong plants that will bloom the first season. 25 cents, $\$ 2.50$ per dozen.

\section{LIATRIS (Blazing Star)}

Natives in various parts of the United States and thrive well in cultivation. The imposing flower spikes of the tall sorts remind one of ascending rockets, so startling is their appearance.

Price of Hardy Perennials, except where :-oted, 10 cents each, $\$ 1.00$ per dozen. 


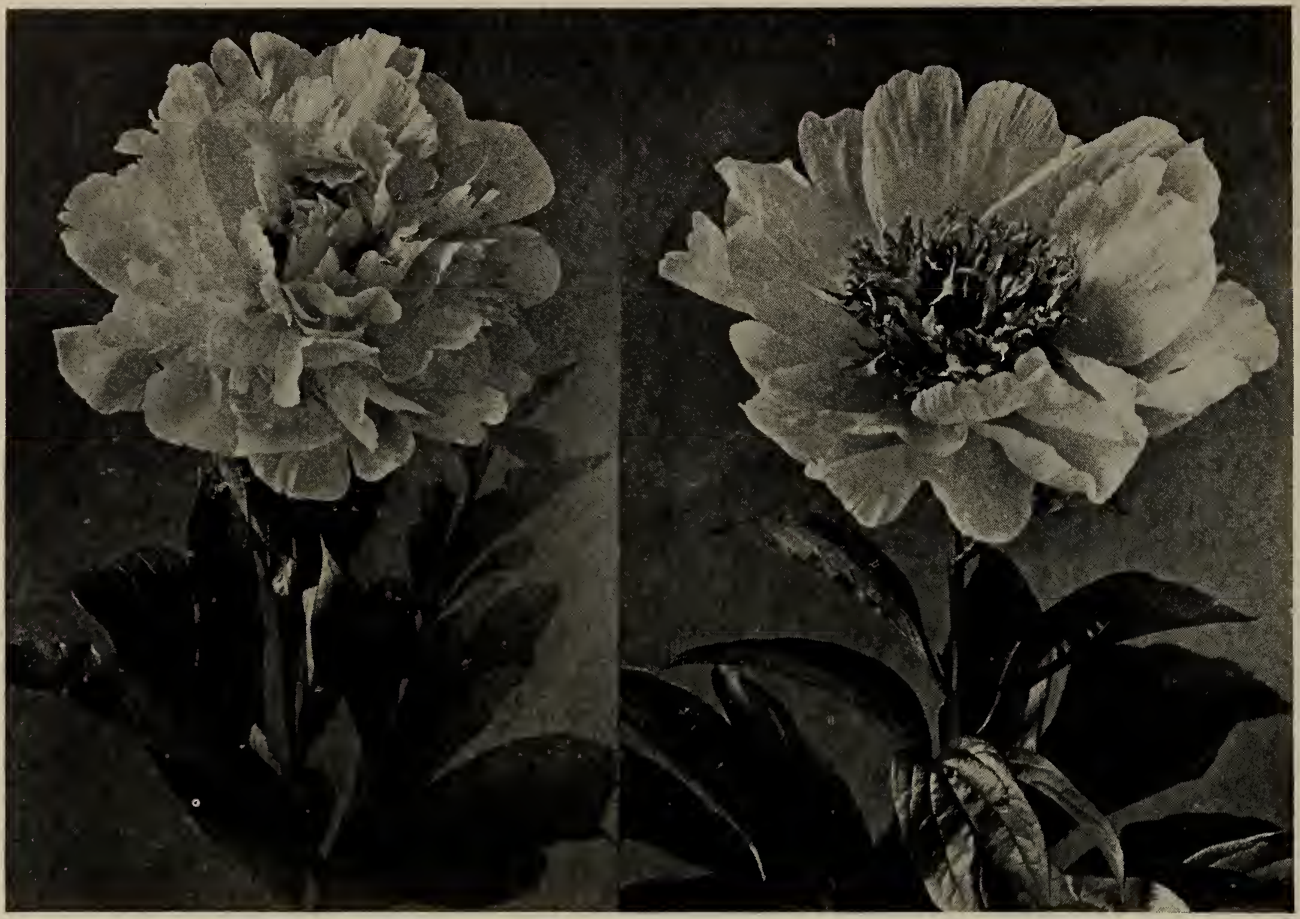

Herbaceous Peony, Festiva.

Liatris longistylis, Button Snalreroot, 11/2 feet; a rare Colorado plant with large showy rose-purple heads in a scattering spike. 25 cents.

Liatris pycnostachia, Kansas Gay Feather, 4-6 feet; dense club-shaped spikes of purple flowers.

Liatris scariosa, Blazing Star, 5 feet; the showy star-like heads are arranged in a long ascending spike which includes two thirds of the total height; very effective among shrubbery; $\$ 1.50$ per dozen.

\section{LILIES.}

Every garden should have Lilies. They are matchless among hardy garden plants for stately habit, beauty of form and variety of color. They commence flowering in May and June, and with the various species maintain a continuous and unbroken succession until frost. If orders for Lilies are received too late for spring planting they will be delivered early in autumn.

Lilium Batemanniae. 3 feet. Rich apricot, unspotted, several flowers on a stem. 20 cents, $\$ 2.00$ per dozen.

Lilium Canadense. 4 feet. An American Lily with yellow bell-shaped flowers spotted with brown. 15 cents, $\$ 1.50$ per dozen.

Lilium Candidum. (Madonna Lily) $3 \mathrm{ft}$. Pure white, fragrant; similar to the Easter Lily but hardy. Large pulbs, 20 cents, $\$ 2.00$ per dozen.
Snow Wheel, Japanese Peony.

Lilium Elegans. 1-2 ft. The var:eties of Lilium elegans are the most distinct of any Lily, varying in color from lemon yellow to crimson, with early and late blooming sorts The following are very distinct.

CLOTH OF GOLD. Orange yellow, unsrotted, 25 cents.

INCOMPARABLE. Deep ox-blood cr'mson, spotted black; very rich. 20 cents.

LEONARD JOERG. Brig. $i$ orange, large flowers and very thrifty. 20 cents.

ROBUSTA. Golden yellow, heavily spotted with dark brown. 20 cents.

Lilium Superbum. $6 \mathrm{ft}$. The most magnificent American Lily; thrives everywhere; flowers 15 to 40 on each stem, orange red.

Lilium Tigrinum.. $3 \mathrm{ft}$. The old-fashioned Tiger Lily; blooms in July.

Lilium Tigrinum Splendens. $4 \mathrm{ft}$. This is as easily grown as the type, the flowers are larger and much brighter in color, more on a stem, and bloom about three weeks later; Rockmont-grown bulbs, strictly true to name; 15 cents, $\$ 1.50$ rer dozen.

Lilium Tigrinum, Double. Perhars the only Lily with perfectly formed double flowers; this is really very beautiful.

\section{LYTHRUM (Loosestrife).}

Lythrum roseum superbum, Roze Loosestrife. A vigorous but graceful plant 2-3 feet tall, numerous spikes of rose-co'ored flowers from July to September. 


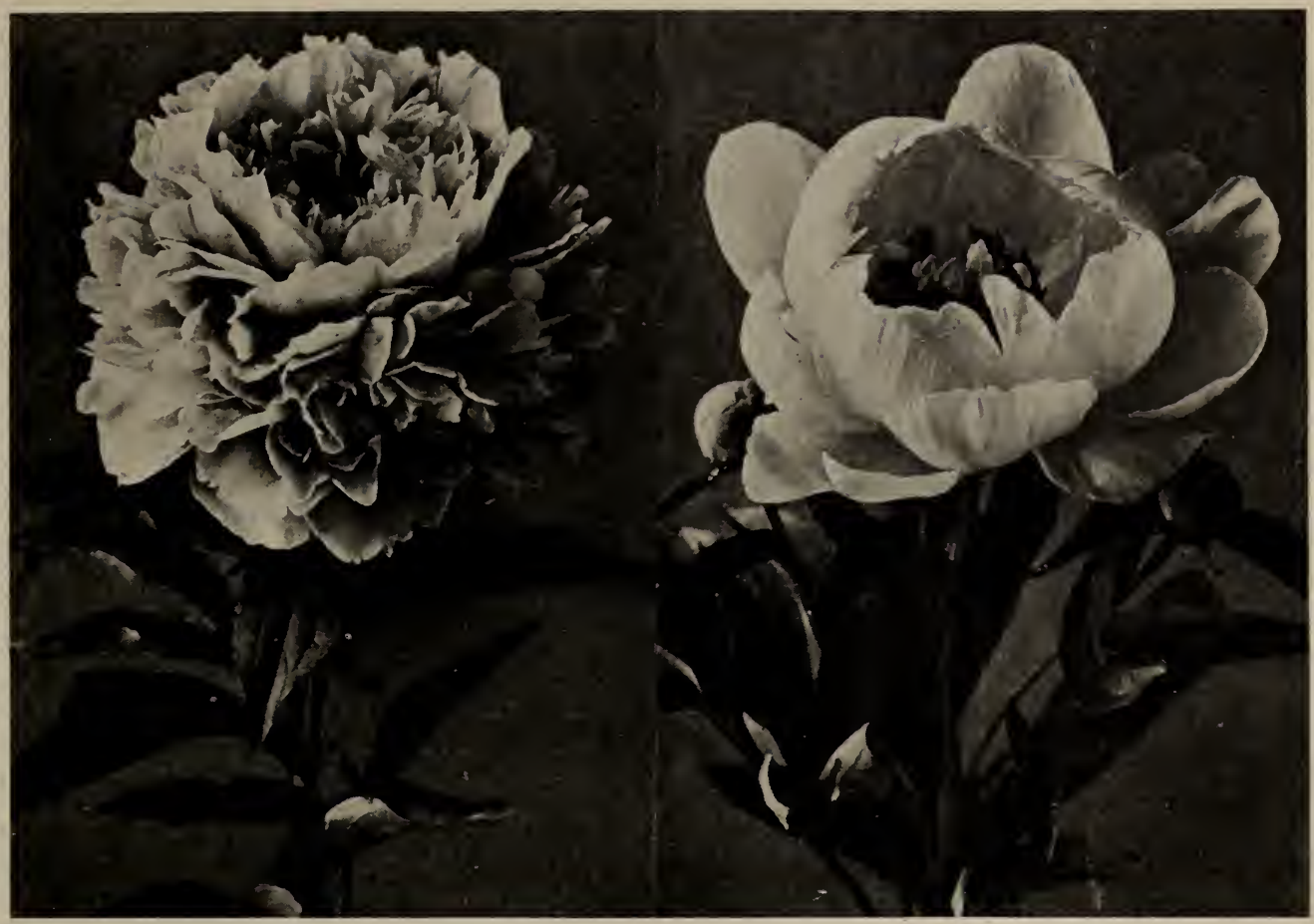

Madam Ducel.

Marie Jacquin.

\section{PEONIES}

Peonies are one of my important specialties. I have a separate four-page leaflet about peonies which will be sent to anyone interested. For this spring I offer the following collections, each selected to include the best possible variety of colors. The plants in these collections are all strong two year o'd roots, several times as large as the " 2 to 3 eye roots" commonly sold. Besides this, they are guaranteed true to name, and I will replace two for every one that proves otherwise. Do not fail to plant reonies early.

\section{COLLECTIONS OF PEONIES DIAMOND COLLECTION.}

Contains sixteen (16) plants, four from each group, and all are choice varieties. If bought separately would cost $\$ 12.80$. I cffer the collection as named below for $\$ 10$.

Alba Sulphurea

Couronne d'Or

Mad. de Verneville

Marie Jacquin

Dorchester
Giganthea

Golden Harvest

Madam Calot

Mad Forel

Masterpiece
Model de Perfection

Mons. Boncharlet Aine

Cardinal Richelieu

Emile Lemoine

Messonier

Mons. Crousse

\section{SILVER AND GOLD COLLECTION}

Contains twelve (12) extra good varieties which would cost $\$ 5.70$ if bought se $\$$ arately; this collection as named below for $\$ 4.50$.

Festiva Maxima

Formosa Alba

Sea Foam

Grandiflora Cárnea Plena
La Tulipe

Mlle. Leonie Calot

Baron James de Rothschild

Floral Treasure
Jeanne d'Arc

Auguste Lemoiner

Delachii

Rubra Superba

Price of Hardy Perennials, except where noted, 10 cents each, $\$ 1.00$ per dozen. 


\section{GEM COLLECTION}

Contains twelve of the older sorts, all good ones and often sold at higher prices. The collection as named, listing at $\$ 4.80$, is offered at $\$ 3.50$.
Festiva
Queen Victoria
Chrysanthaemiflora
Nec Plus Ultra
Achillea
General Cavaignac
Andre Lauries
Humei Carnea

\author{
Rosea Superba \\ Atrosanguinea \\ Louis Van Houtte \\ Marechal Vallaiant
}

NOTE. The three collections above contain forty (40) plants, all different varieties and the price for the three collections, $\$ 18.00$.

\section{CHAMPION ASSORTMENT}

In this assortment I offer twenty five (25) plants in ten good named varieties, the choice of varieties to be left entirely with me, but some will be included from the various colors. The price of this assortment, $\$ 5.00$.

\section{JAPANESE COLLECTION}

The Japanese Peonies are single, having large petals, and a center composed of narrow twisted filaments as shown in our photograph of "Snow Wheel," or of yellow stamens. Some of the flowers are distinctly cupped like Marie Jacquin. All of the following six varieties will be a joy to those who love single flowers. I offer single plants at the prices named, or the collection for $\$ 4.00$.

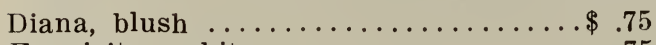

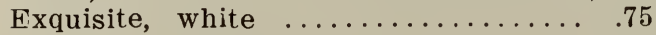

Neptune, deep rose ........... 1.00

\section{HARDY PHLOX.}

A very important group of nardy plants having a wide range of color, a long season of b'oom and succeeding in almost any soil or position. For best results they should have a friable soil that will not bake, and plenty of water during the blooming season, as they are quite sensitive to drought. Partial shade is desirable, as continuous sunshine results in smaller flowers and the bleaching of certain colors.

The best effects to be had with phlox are produced by planting masses of each color, care being taken in grouping to bring harmonious shades together. Realizing that a large number of kinds is confusing to the purchaser, I include only those which are most distinct and the best of each color. Price of Phlox, except as noted, 10 cents each, $\$ 1.00$ per dozen.

Consul H. Trost, a sūperì pure red with crimson eye; 15 cents, $\$ 1.50$ per dozen.

Coquelicot, orange-scarlet, very brilliant; 15 cents, $\$ 1.50$ per dozen.

Eclarieur, carmine-rose, large light halo; large flower.

F. G. von Lassburg, the largest and finest pure white, flower as large as a silver dollar; 15 cents, $\$ 1.50$ per dozen.

Huxley, a fine clear lavender.

Henry Murger, enormous pure white flowers with large brilliant carmine center. ity.

Le Mahdi, very deep purple of fine qual-

Miss Lingard, pearly white flower with faint violet eye; a remarkable bloomer, being constantly in bloom from June till late frost; foliage glossy; the best phlox for cutting.

Peachblow, delicate peachblow-pink.
Snow Wheel, white $\ldots \ldots \ldots \ldots \ldots \ldots 1.00$

Topaz, pink .................... .75

Vesta, rose-red $\ldots \ldots \ldots \ldots \ldots \ldots \ldots . .75$

R. P. Struthers, clear cherry-red, suf. fused salmon, deep red eye.

\section{PLATYCODON (Chinese Bell-flower).}

Platycodon grandiflora, $1 \frac{112}{2}$ feet; broad bell-shaped flowers of large size, deep blue or pure white; blooms throughout the summer; assorted, 15 cents, $\$ 1.50$ per dozen.

\section{OROBUS (Rosy Vetch).}

Orobus niger, $11 / 2$ teet; little upright bushes, literally covered during the summer with small rosy pea-shaped flowers; 15 cents, $\$ 1.50$ per dozen.

PARDANTHUS (Blackberry Lily).

Pardanthus Sinensis, 2 feet; small orange lilies which are followed by blackberry-like fruits; easily grown.

RUDBECKIA (Black Eyed Susan).

Rudbeckia Newmanni, $1 \frac{1}{2}$ feet; next to the Shasta Daisy, this is the most popular rlant with daisy-like flowers; forms large bushy clumps bearing on long stems a profusion of exceedingly decorative flowers with golden yellow rays and brown coneshaped centers. Thrives in any sunny position; $\$ 1.00$ per dozen, $\$ 6.00$ per 100 .

\section{SALVIA (Flowering Sage).}

Salvia azurea grandiflora. Blue Sage. Three to four feet tall, pale blue flowers in early autumn; very fine for cutting; 15 cents each, $\$ 1.50$ per dozen.

Salvia Pitcheri. Same as the last, but with flowers deep indigo blue, and blooms about two weeks later, continuing till severe freezing weather. One of the finest blue flowers for cutting; 15 cents each, $\$ 1.50$ per dozen.

\section{SHASTA DAISY, "ALASKA."}

Burbank's Alaska Daisy, $1 \frac{1 / 2}{2}$ feet. A flower of magnificent size, yet of exquisite refinement. Its first qualification is extreme 


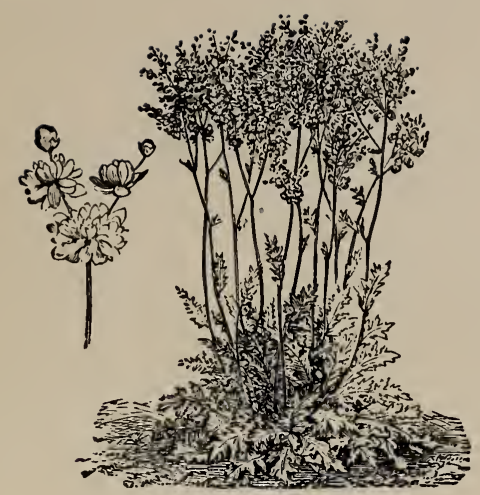

Spiraea filipendula.

hardiness; second, it is perennial, blooming better each season; third, it blooms nearly all summer; fourth, the flowers, four inches or more in size, have petals of glistening white, on single long wiry stems and remain fresh a long time when cut. No other flower can compare with it in usefulness; 15 cents, $\$ 1.50$ per dozen.

SPIRAEA (Meadow Sweet).

The herbaceous spiraeas are distinct from the shrubby sorts, and are very useful plants for the flower border with panicles or plumes of pink or white flowers on long stems suitable for cutting; they are easily grown in ordinary soil, tneir special requirement being an abundance of moisture. Price, except where noted, 15 cents, $\$ 1.50$ per dozen.

Spiraea Aruncus. Goat's Beard. Long feathery panicles of white flowers in June and July; $3-5$ feet tall.

Spiraea filipendula plena, Dropwort. (See cut). Numerous corymbs of white flowers, on stems two feet tall, pretty fernlike foliage.

Spiraea Gigantea. Forms a bold clump 5 to 6 feet high, with palmate leaves and immense heads of small white flowers; July to September. 20 cents each., $\$ 2.00$ per dozen.

Spiraea lobata. Meadow Sweet. Large feathery plumes of carmine rose flowers. 25 cents, $\$ 2.50$ per dozen.

Spiraea UImaria plena. An elegant variety with double white flowers.

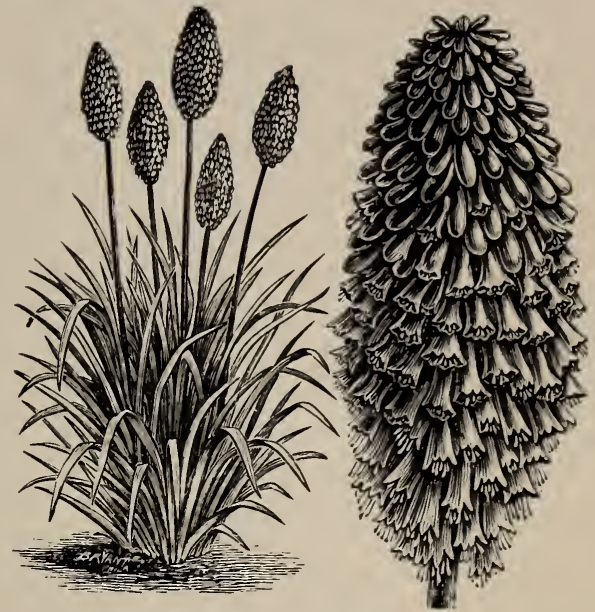

Tritoma Pfitzeri.

TRITOMA (Torch Lily).

Tritoma Pfitzeri, $2 \frac{1}{2}$ feet; no flower concels such instant attention and admiration as the Torch Lily or Red Hot Poker. This truly ever-blooming variety surpasses the finest Cannas or Gladiolus in attractiveness and brilliancy ; it blooms freely the same year it is planted; 20 cents, $\$ 2.00$ per dozen.

\section{VERONICA (Speedwell).}

Veronica longiflora subsessilis. Long spikes of very deep blue flowers on stems two feet tall; very showy and fine for cutting. 25 cents, $\$ 2.50$ per dozen.

Veronica Virginica, Taller, with spikes of white flowers.

\section{YUCCA (Spanish Bayonet).}

Yucca glauca. Known locally as Soapweed; a very hardy native with stiff evergreen foliage and very large white or purple tinted flowers; can be grown in dry bleak or exposed positions. $\$ 1.50$ and $\$ 2.50$ per dozen.

Yucca filamentosa. Among the very best of foliage and flowering plants and is much used in landscape planting among shrubs and in groups, and is effective and at home anywhere. The Yuccas are evergreen, and for tropical effects are unequalled among hardy plants. $\$ 1.50$ and $\$ 2.50$ per dozen. 
$$
\text { - }
$$ 

